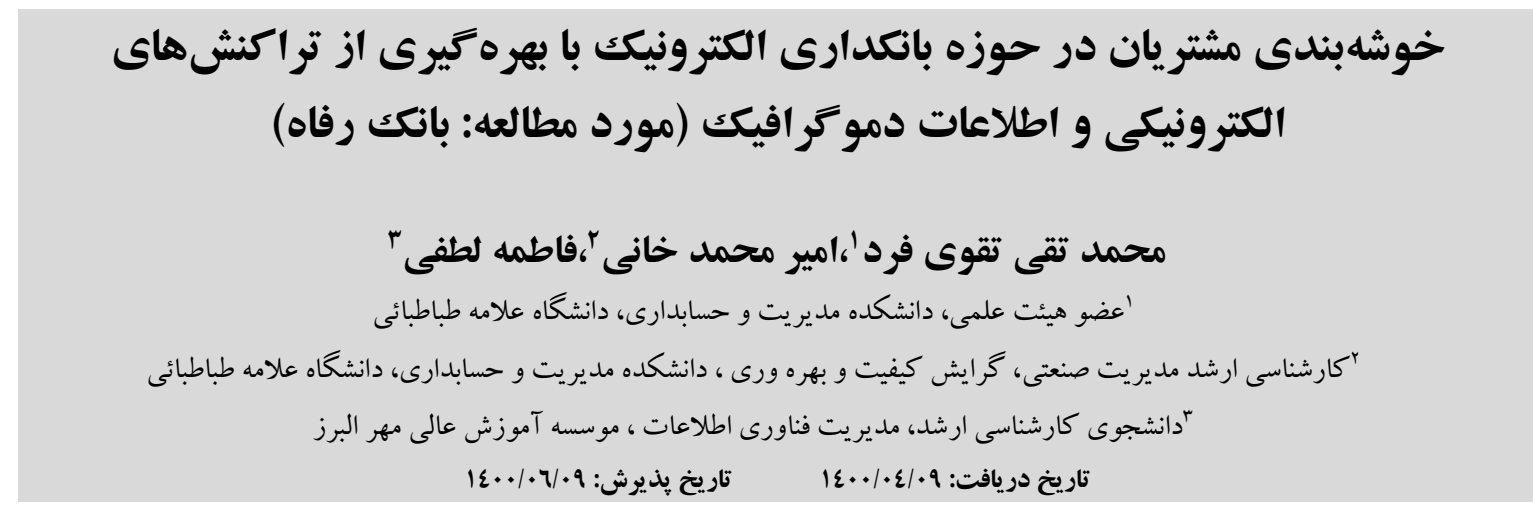

\title{
Strategy As Thoughts Multiplicity: The Innovative Participatory Learning Metaphor-Drama Research
}

\section{Mohammad Taghi Taghavifard', Amir Mohammad Khani², Fatemeh Lotfi $^{3}$}

${ }^{1}$ Faculty Member, Faculty of Management and Accounting, Allameh Tabatabai University

${ }^{2}$ Master of Industrial Management, Quality and Productivity, Faculty of Management and Accounting, Allameh Tabatabai University

${ }^{3}$ M.Sc. Student, Information Technology Management, Mehr Alborz Institute of Higher Education Received: (30/06/2021) Accepted: (29/08/2021)

\section{شناسه يكتا:https://dorl.net/dor/}

\section{Abstract}

Knowing customers and identifying profitable services is of great importance due to the diversity of bank customers and the variety of services in the country's banking system. Customer relationship management is currently the core of the business world, the most important interbank network used in Iran is the Shetab network. In this research, data mining techniques are used to segment and rank customers in the Shetab network, using an improved data mining model based on recent purchasing, purchase frequency and amount spent on purchases so that banks can behave in this network. Analyze and evaluate your customers and formulate effective policies in dealing with customers. Also, in order to review similar studies and increase information through library and internet studies, information related to the model was collected. Finally, $\mathrm{R}+$ FMW presented a model for clustering bank customers and their transactions. The results showed that the developed $\mathrm{R}+$ FMW model has a higher accuracy than the basic RFM model, and using this model, banks can identify customers active in the interbank exchange network (acceleration) and customers and costly communication channels. In terms of fees and demographic information.

Keywords

Data Mining, Classification, Clustering, Banking, Customer Ranking, Customer Relationship Management,

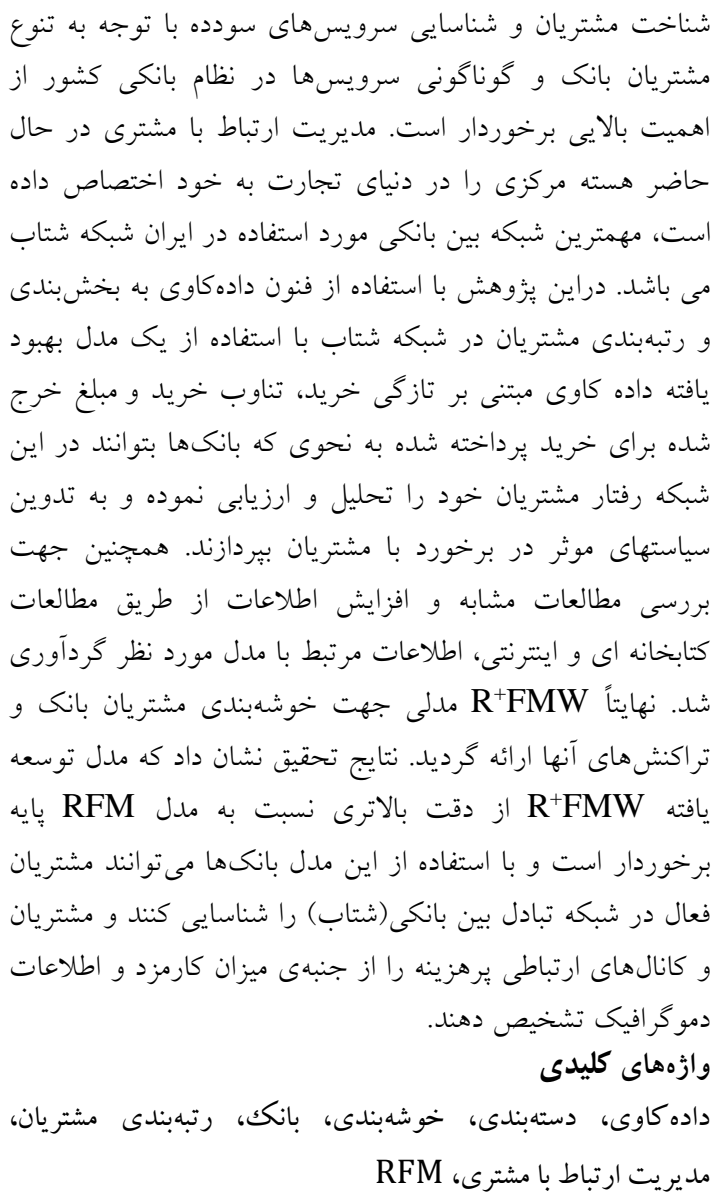


تقوى فرد ،خانيو لطفى:خوشهبدى مشتريان در حوزه بانكدارى الكترونيك با بهره گيرى از تراكنشهاى الكترونيكى و اطلاعات دمو گر افيك (مورد

مطالعه: بانكك رفاه)

ذكر است كه رويكرد اين واحد نيز در قبال مشتريان عمدتاً (مقدمه

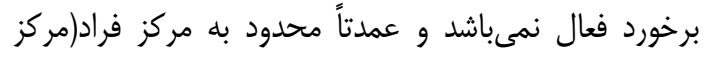

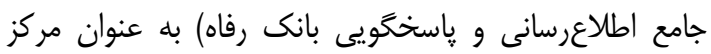

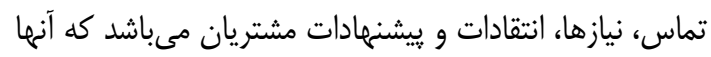

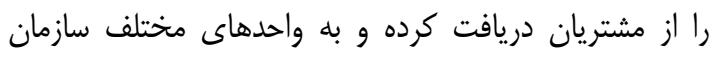

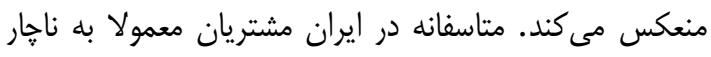

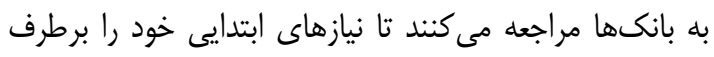

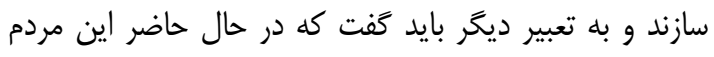

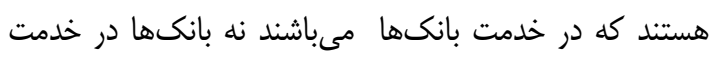

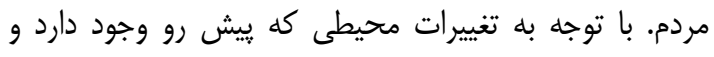

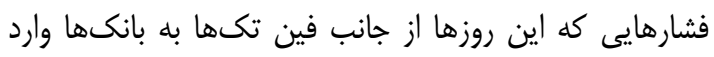

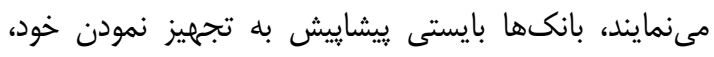

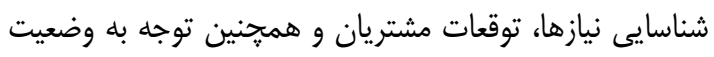

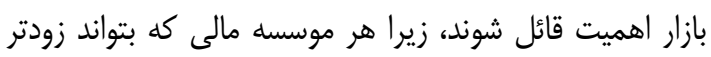

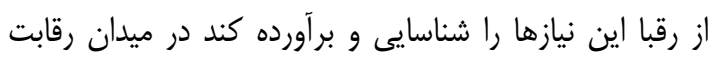

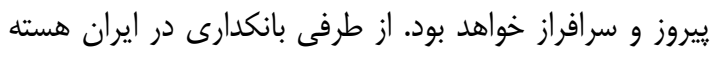

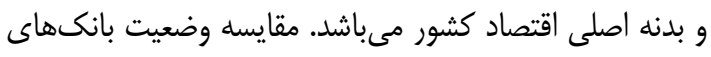

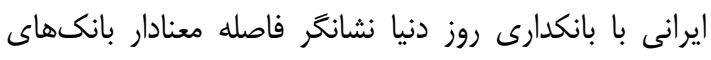

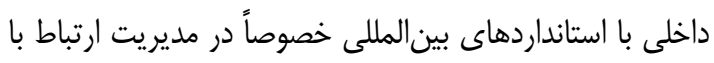

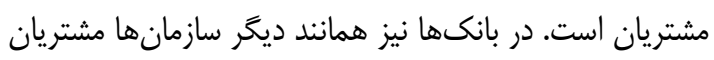

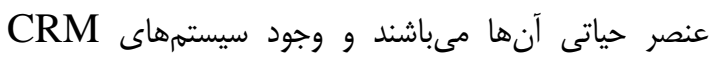

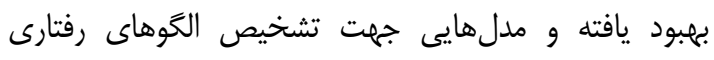

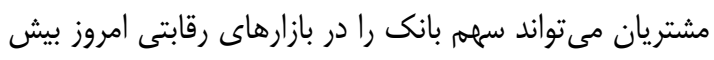

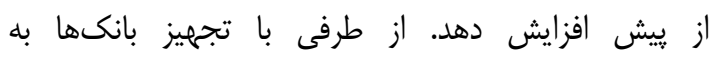

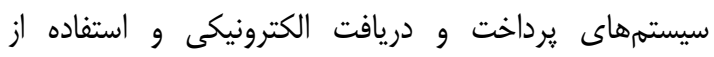

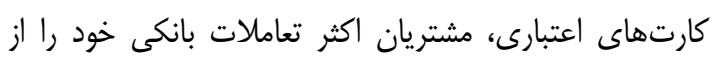

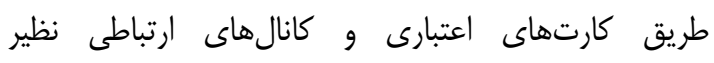

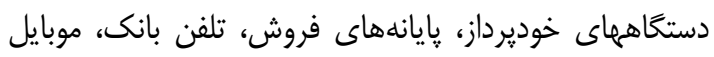

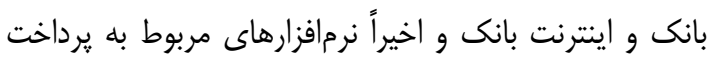

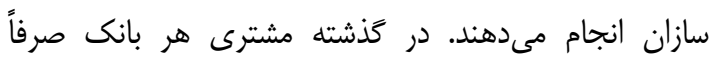

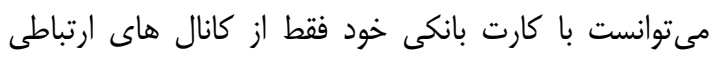

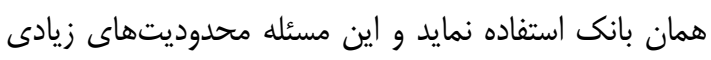

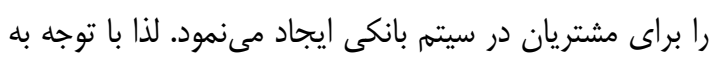

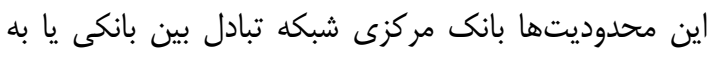

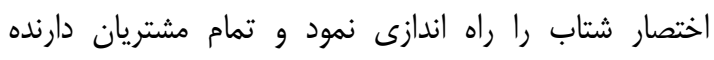

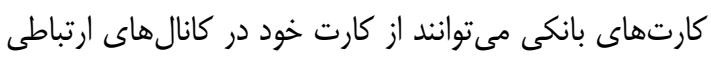

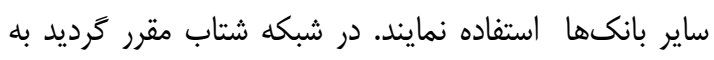

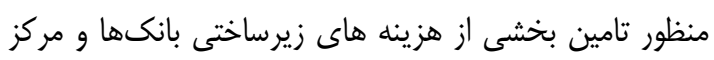

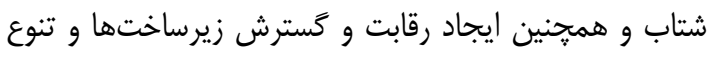

امروزه در هر سازمان مهمترين عنصر مشترى است. در بازار

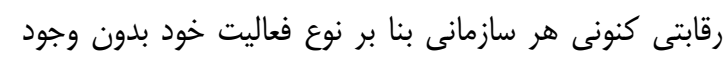

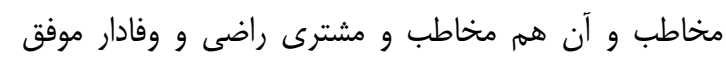

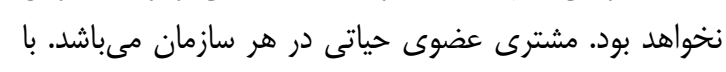

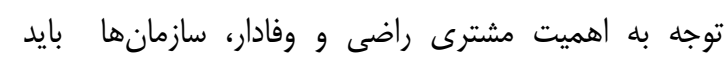

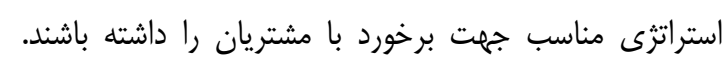

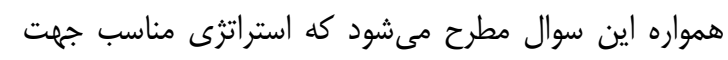

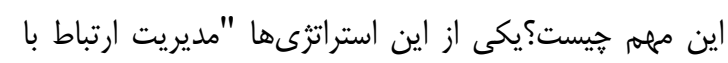

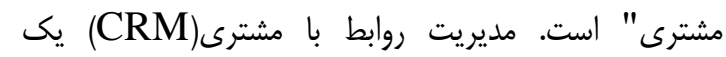

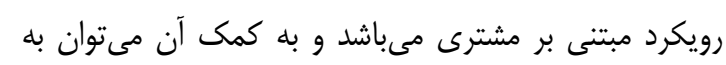
ايجاد، نتحهدارى و بهبود روابط مشترى مئرى با سازمان يرداخت.

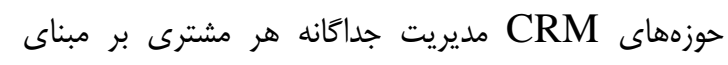

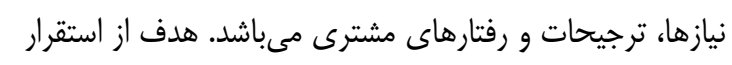

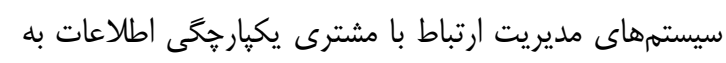

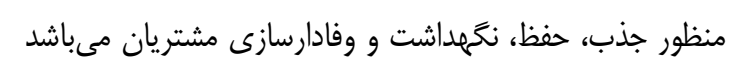
و در نهايت بر اساس اطلاعات جمعآورى شده نداءئ سازمان

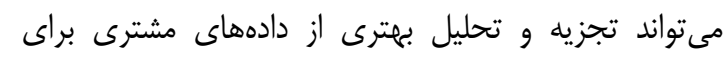

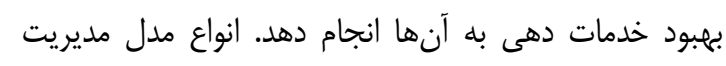

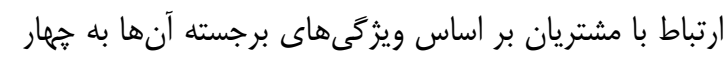
دسته اصلى استراتزيك، عملياتى، تحليلى و تعاملى تقسيم

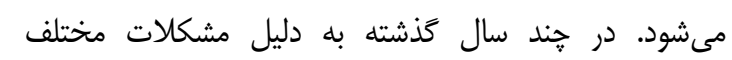

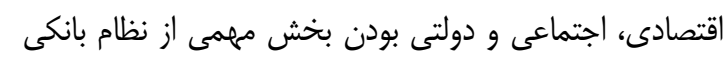

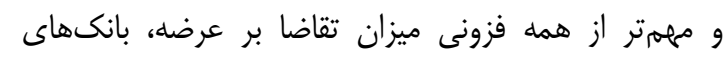

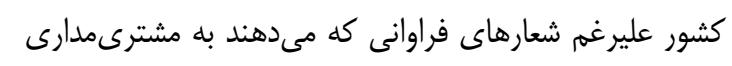

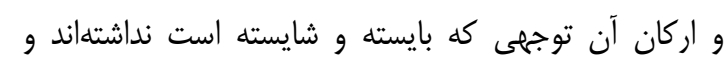

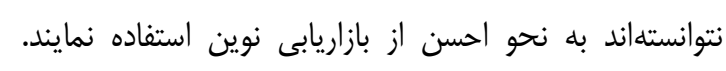

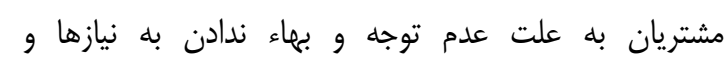

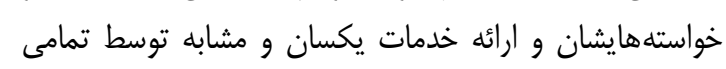

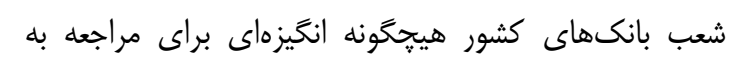

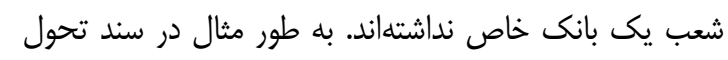

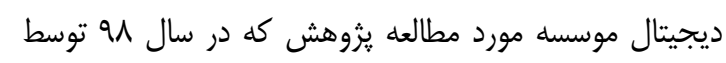

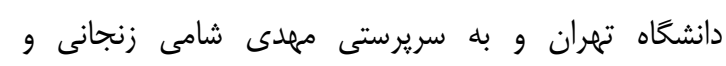

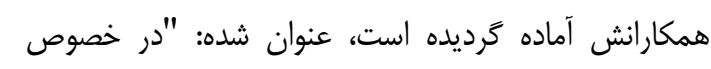

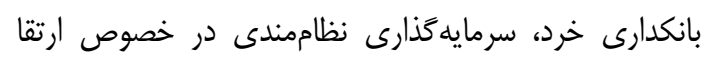

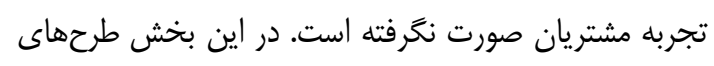

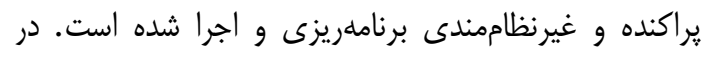

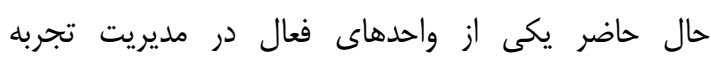

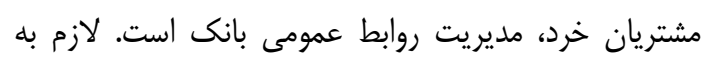


يافته تحليل RFM مىباشد كه R+FMW نام كرفته است. نوآورى دوم قابليت اعمال مدل بر روى مجموعه دادي داده

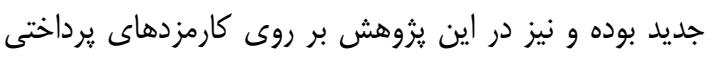

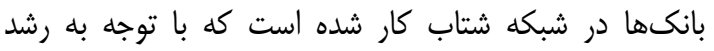

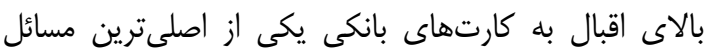
يبش روى موسسات مالى مىباشد و تحقيقات نادرى در اين باني مورد صورت يذيرفته است.

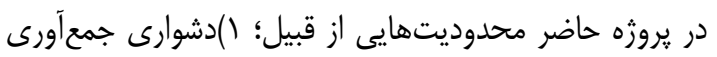

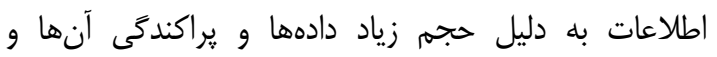

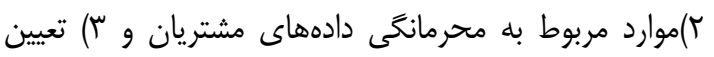
تعداد خوشه بهينه از جانب دستاندر كاران موسسه وجود داشتئ

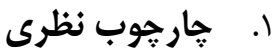 \\ r- ا بخشبندى مشتريان}

190. مفهوم بخشبندى مشتريان براى اولين بار در سال

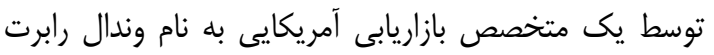

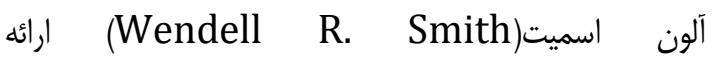
كرديد.(تسييتيس، +. +א).فرآيند تقسيم يا بخشبندى كل

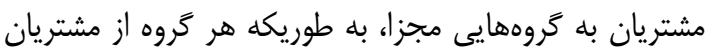

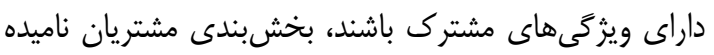

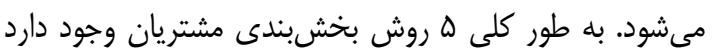

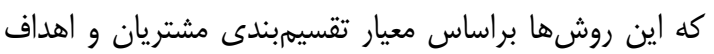

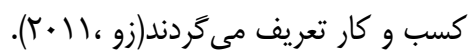

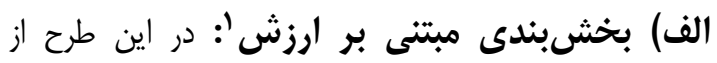

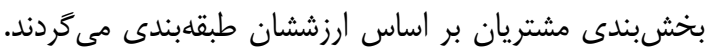

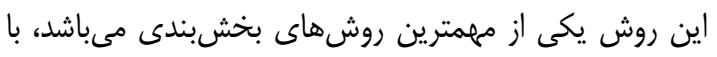

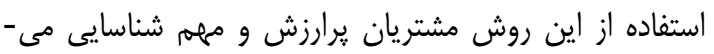
شوند و مىتوان تغييرات ارزش را در زمان دنبال كرد.

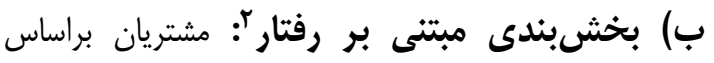
الكَى رفتارى تقسيم مى شوند.

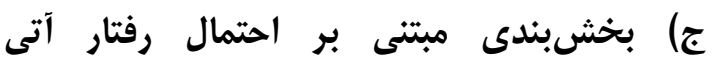

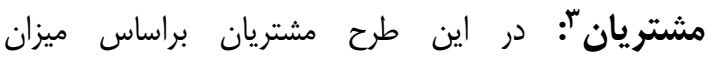

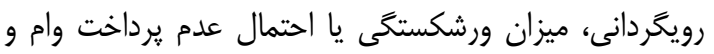

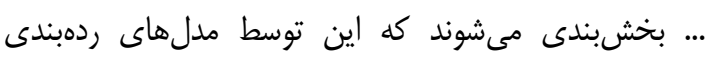

تخمين زده مىشوند.

\footnotetext{
${ }^{1}$ Value Based Segmentation

${ }^{2}$ Behaverial Segmentation

${ }^{3}$ Propensity baseless Segmentation
}

در ارائه خدمات به مشتريان خُنانجه مشترى يك بانكى از بانكان كارت بانكى خود بر روى كانالهاى بان بانكهاى دئ ديخر استفاده

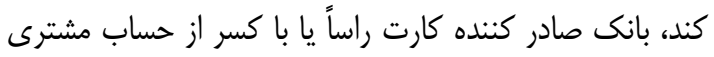

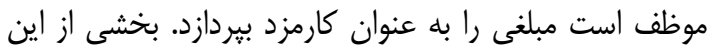

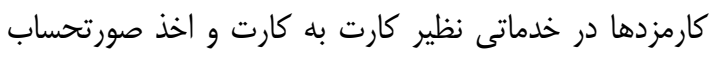

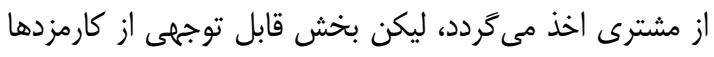

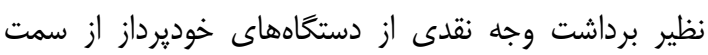

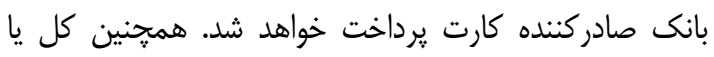

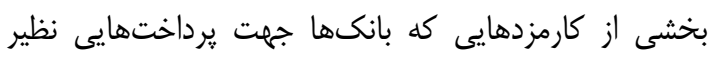

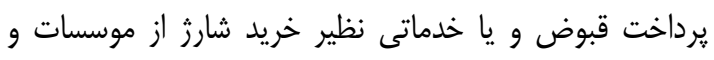

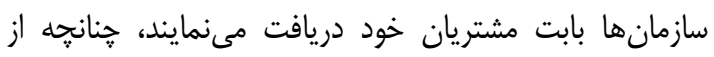

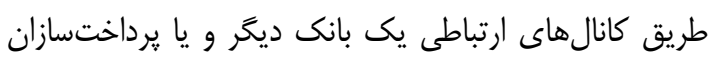

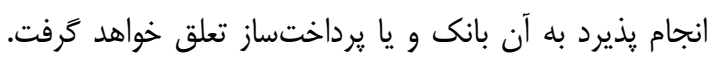

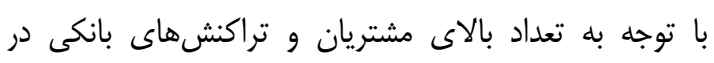

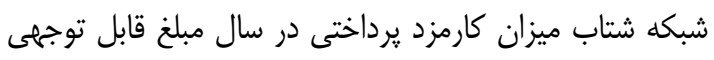

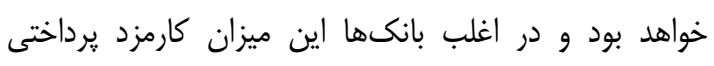

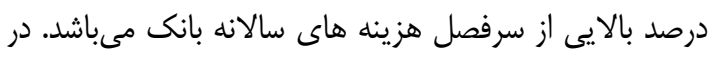

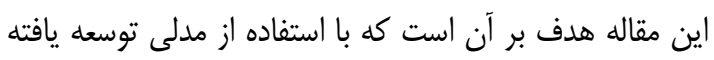

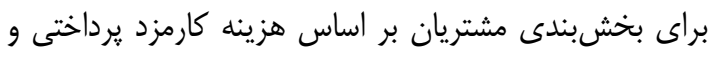

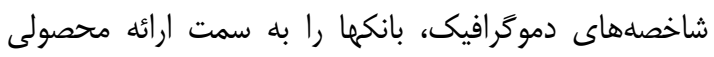
مناسب با وضعيت شخص و و راهنمايى موثر مشتريان آنانيا آشنا

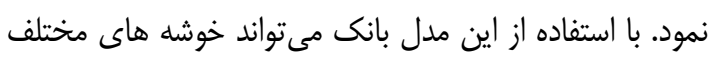

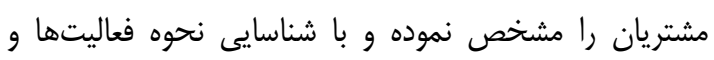

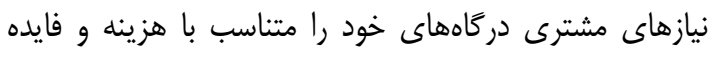

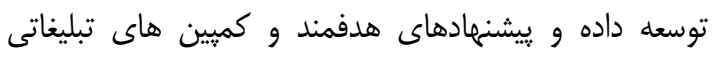

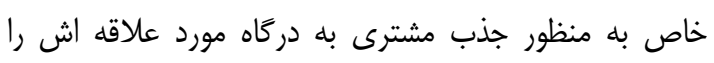

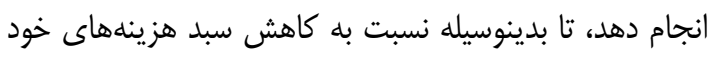

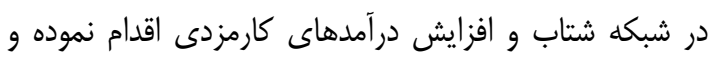

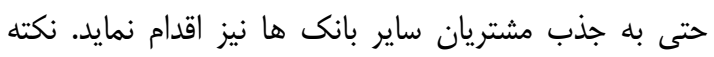

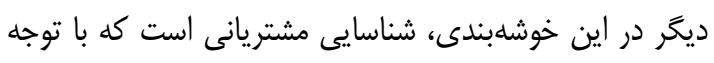

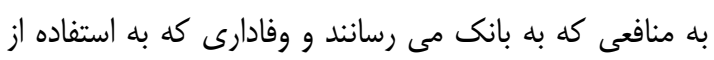

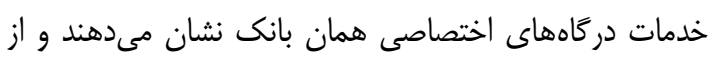

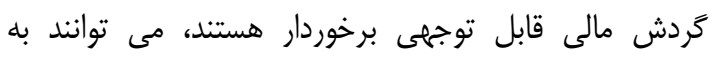

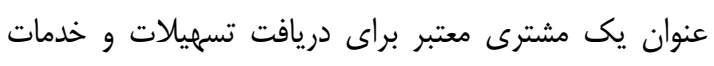
ويزه شناسايى تردند.

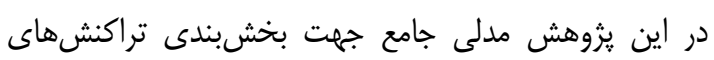

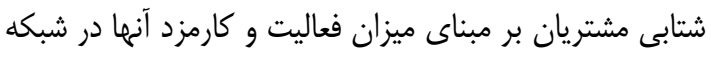

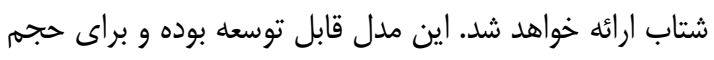

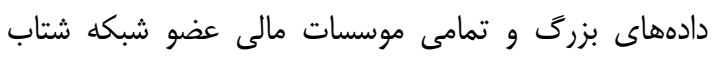

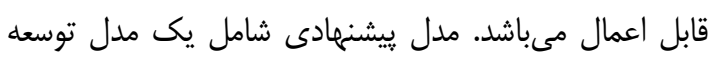


تقوى فرد ، خانيو لطفى:خوشهبندى مشتريان در حوزه بانكدارى الكترونيك با بهره گيرى از تراكنشهاى الكترونيكى و اطلاعات دمو كرافيك (مورد

مطالعه: بانكك رفاه)

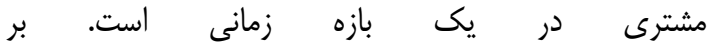

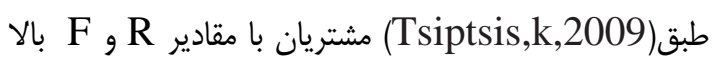
احتمالاً در آينده نزديك نيز با سازمان تعامل خواهند داشت.

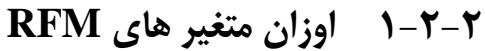

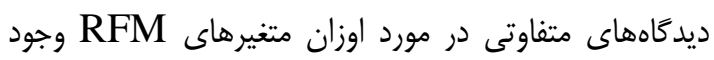

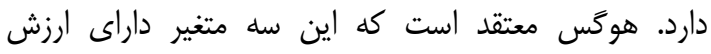

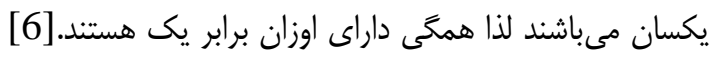

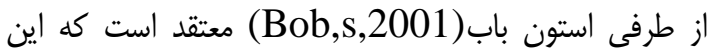
سه متغيير بسته به كاربردشان در صنعت از درجه اهميت إنايت متفاوتى برخوردارند.

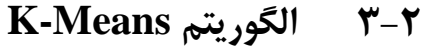

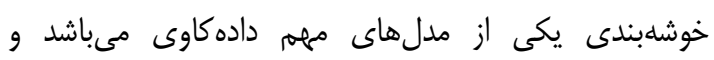

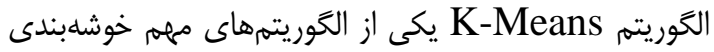
است. فرايند كَروه بندى اشياء فيزيكى يا انتزاعى به كَروههاى

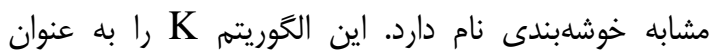
ورودى كه بيانكر تعداد خوشههاست دريافت كرده و داده را به K خوشه افراز مى كند. تخصيص دادهها به خوشهها

بر اساس فاصله اقليدسى دادهها از مراكز خوشه مى باشد. بر طبق تسيتيس از الكوريته

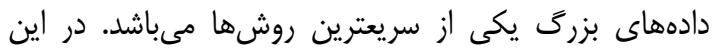

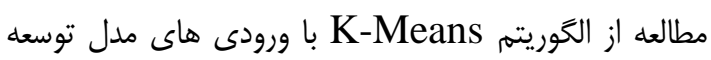
يافته RFM استفاده كرديده است. همجنين با توجه به هدف اين يثوهش كه شناسايى مشتريان

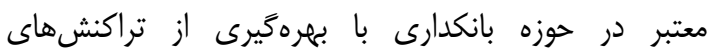

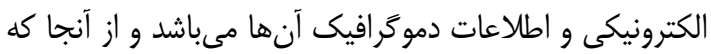
از تكنيك RFM و همجنين الكوريتم K-means استفاده

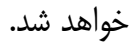
در ادامه به برخى يُوهشهاى خارجى و داخلى انجام يذيرفته و به توسعه مدل RFM اقدام نمودهاند اشاره كَرديده است. يزوهش شماره () ) تحقيق در مورد مدل تقسيم مشترى بهببود

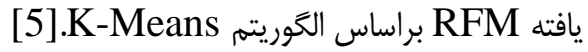

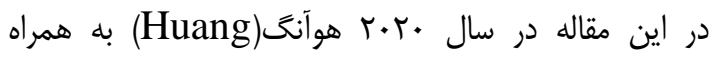
همكاران به مشكلاتى كه در مدل RFM در صنعت خرده

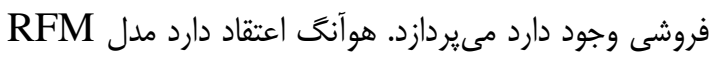
كه براى تقسيمبندى مشترى در صنعت خرده فروشى سنتى استفاده مى شود، براى صنايع با صفات متمايز كروههاى

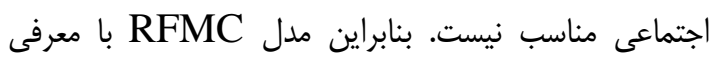
يارامتر C كه به روابط اجتماعى اشاره دارد را ارائه مى دهد.

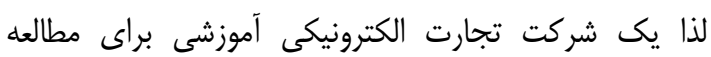

د) بخشبندى مبتنى بر وفادارى': اين طرح از بخشبندى شامل بررسى وضعيت وفادارى مشتريان مىباشد به طوريكه مشتريان وفادار به سازمان و مشتريانى كه رويخردان بودند را مشخص كنند.

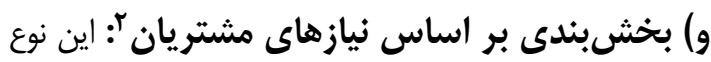
بخشبندى براساس اطلاعاتى كه از تحقيقات در بازار صورت مى گيرد انجام مىشود و مشتريان را براساس نيازها، خواسته ها، علايق آنها گروهبندى مى مئمايد.

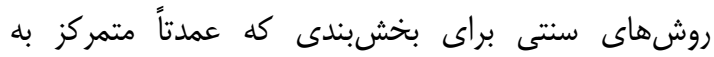

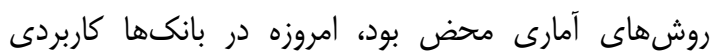
ندارند. علت عدم كاربرد اين روشها حجم باري بسيار زياد دادههاى

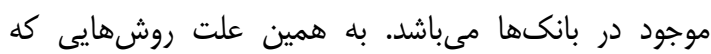

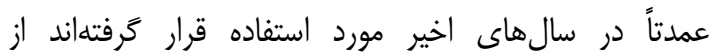

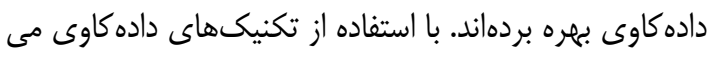

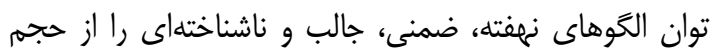

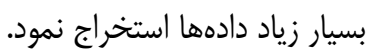
در اين مقاله يك طرح تحليل رفتار مشتريان بانك بر مبناى

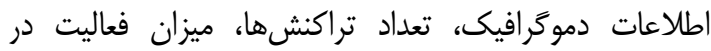
دركاههاى بانك و هزينه و فايده مشتريان در شبكه شتاب تراب ارائه مى گردد. براى انجام هر كدام از انواع روشينه

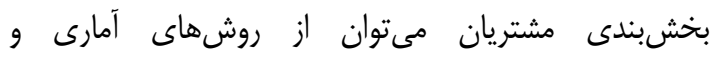

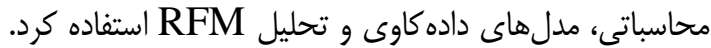

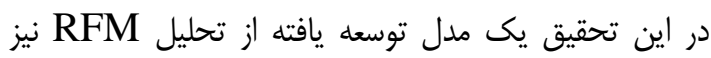
مورد استفاد قرار خواهد كرفت.

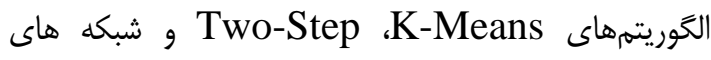
عصبى از مدلهاى يركاربرد دادهاوى در بخشبندى مشتريان مىباشند.

مدل بيشنهادى اين مطالعه تركيبى از الكوريتم RF-Means مدئن

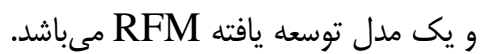

RFM r-r تحليل مدل تحليل RFM در سال 1994 توسط آرتور هوگس

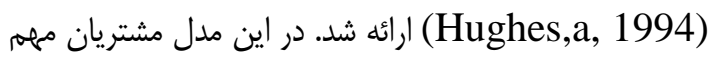

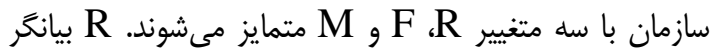

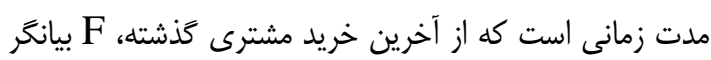
تعداد خريدها يا تراكنشهاى مشترى در يك إنى برين بازه زمانى مشخص مى باشد و M نشاندهندهى مجموع مبالغ خريدهاى

\footnotetext{
${ }^{1}$ loyality based Segmentation

${ }^{2}$ Needs/ attitudinal Segmentation
} 


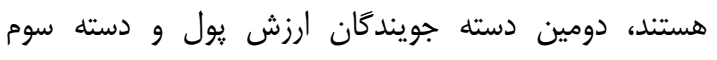

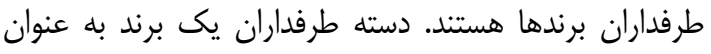

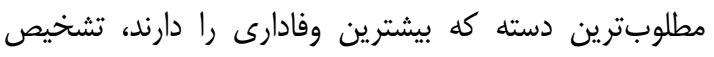
داده شده است. اين دسته ابزارى بسيار مناسبى براى تبليغات

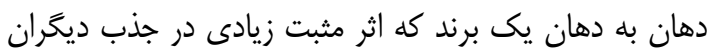

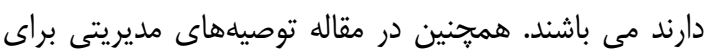
اجراى كميبنهاى وفادارى كه متناسب با مشخصات جمعيتى دمانى و رفتارى هر بخش مى باشد، ارائه شده است.

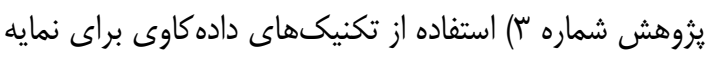

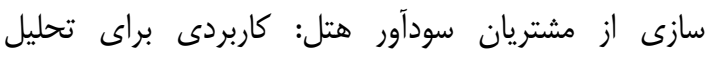

RFM

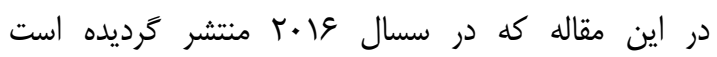

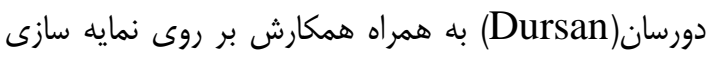

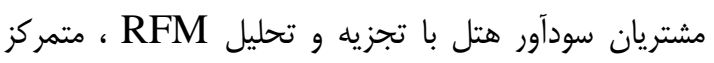

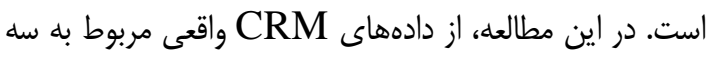

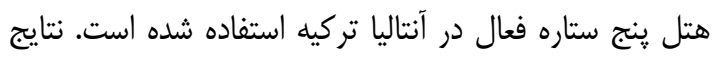

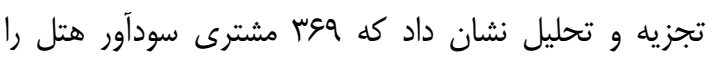

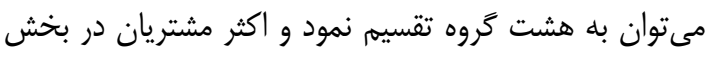

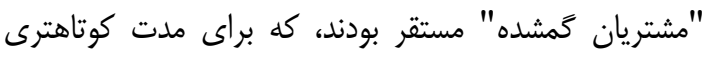

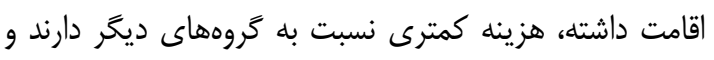

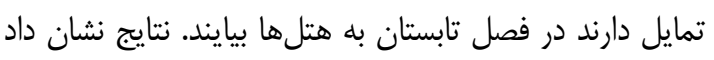

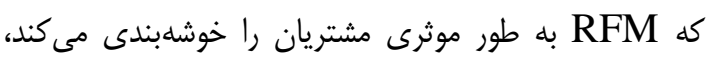

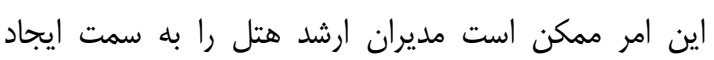

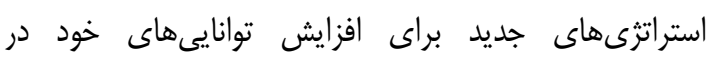

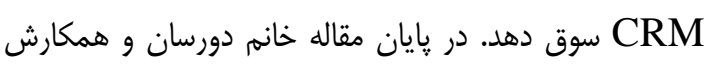

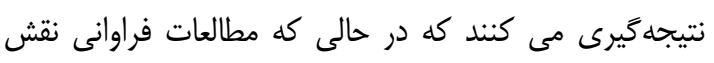

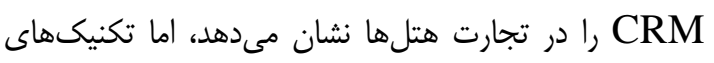

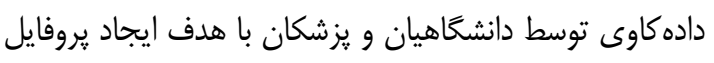

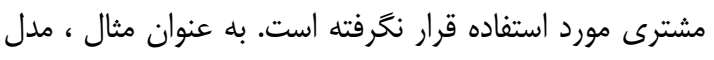

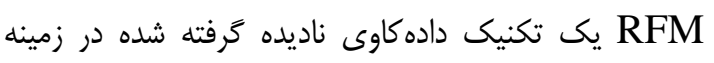

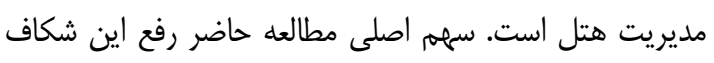

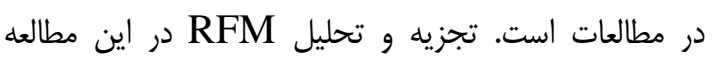

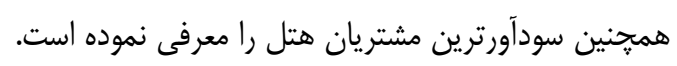

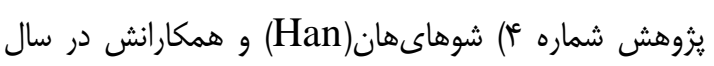

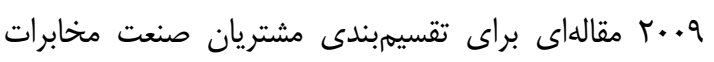

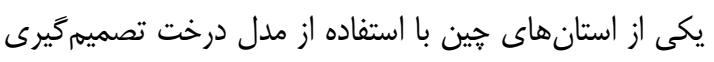

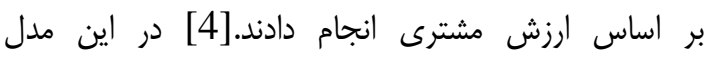

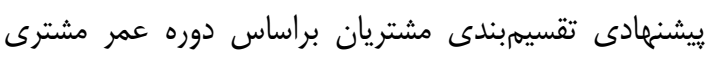

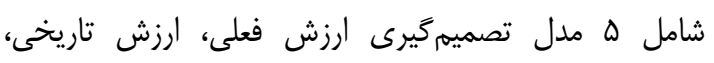

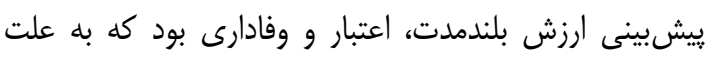

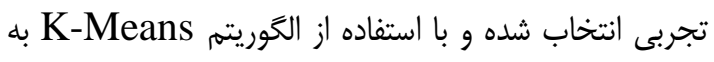

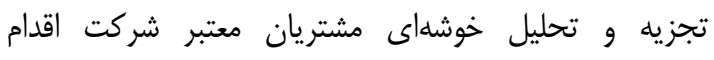

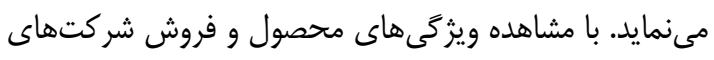
تجارت الكترونيكى آموزشى، اين مطالعه مقادير ارتباط جامعائ

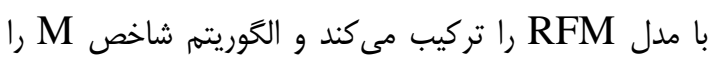

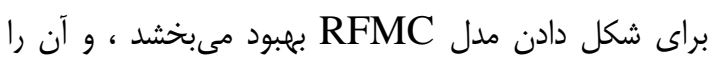
براى شركتهاى تجارت الكترونيكى مناسبتر مى كند.

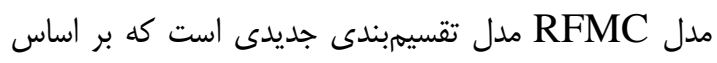

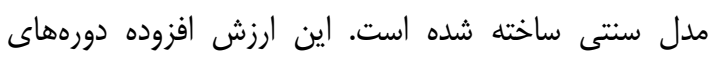

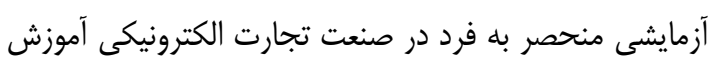

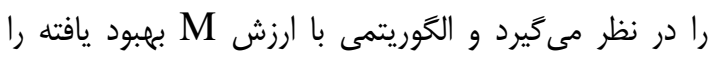

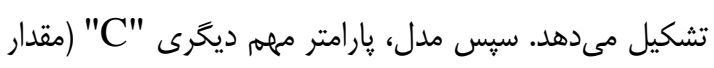

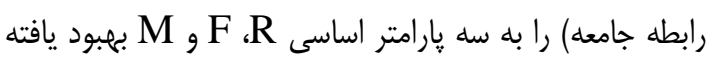

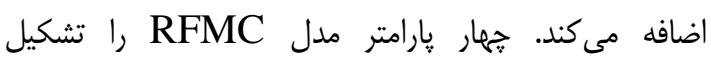

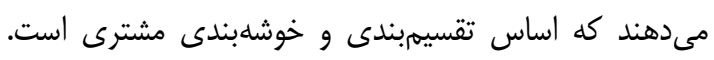
جهار بارامتر به شرح زير تعريف شده است:

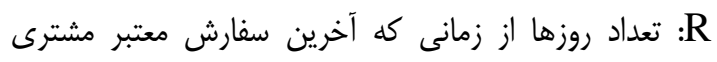

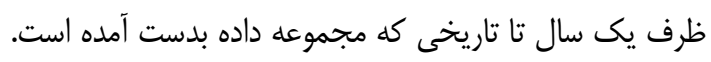

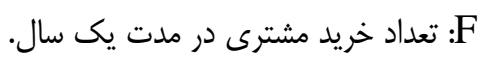

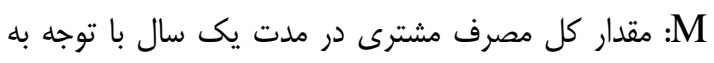

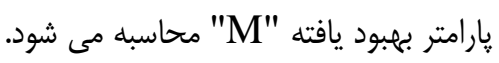

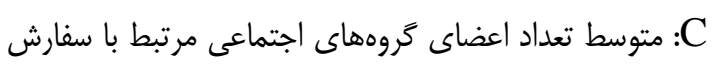

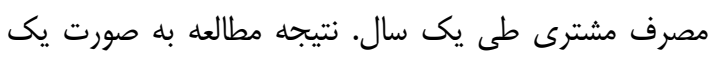

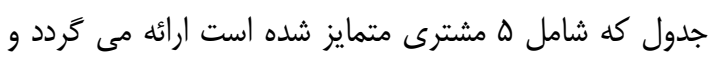
اثربخشى مدل را تأييد مى كند.

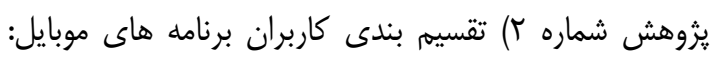

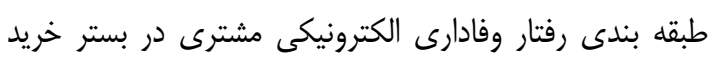
آناين.

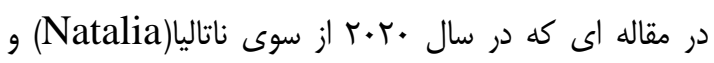

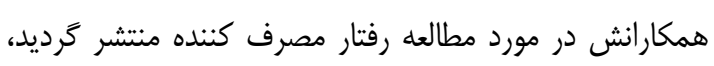

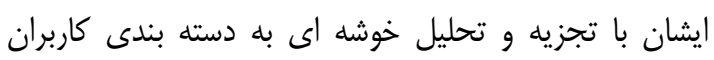

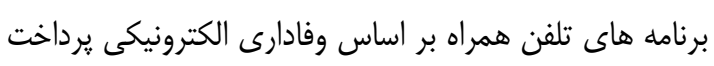

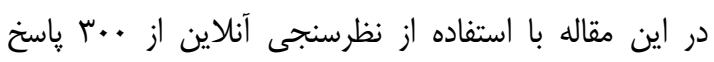

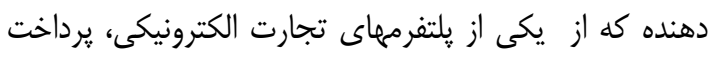

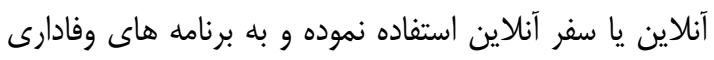

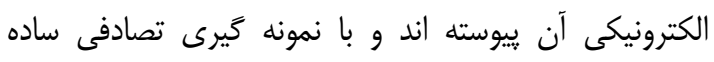

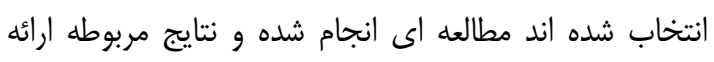

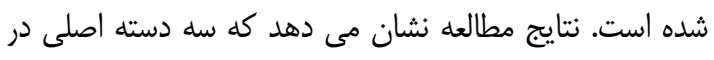
اين افراد وجود دارند، اولين دسته جويندكان درمانهان دهاى ويثه دهان 
تقوى فرد ،خانيو لطفى:خوشهبدى مشتريان در حوزه بانكدارى الكترونيك با بهره گيرى از تراكنشهاى الكترونيكى و اطلاعات دمو گر افيك (مورد

مطالعة: بانكك رفاه)

برمبناى تحليل رفتار مشترى: مورد مطالعاتى.

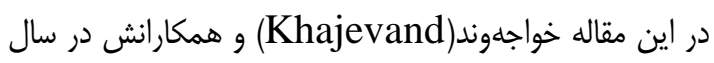

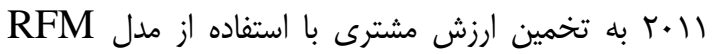

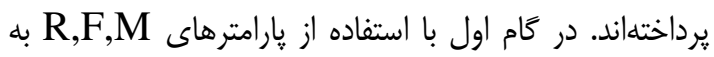

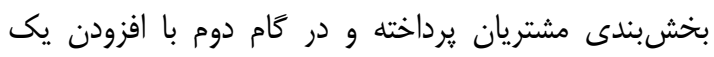

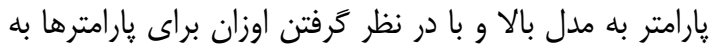

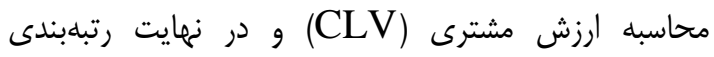

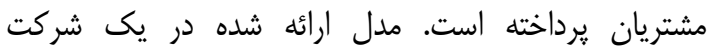

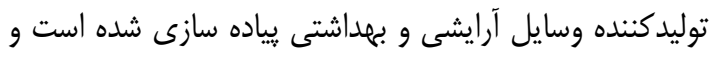

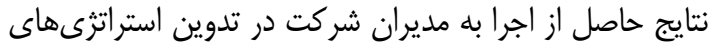
فروش و بازاريابى كمى نموده است. يزوهش شماره 9) تقسيم بندى رفتارى مشتريان دستخاههاى

PFM بانك با رويكرد POS

دستخاههاى POS سيستمهاى برداخت الكترونيكى بانكها

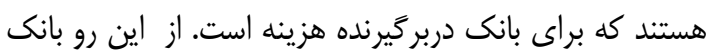

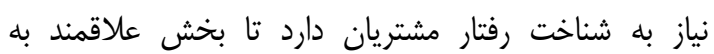

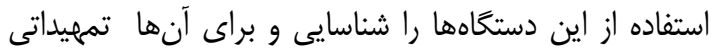
در نظر بحيرد كه هم مشتريان راضى و هم بانكى به مشتريان

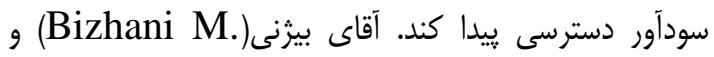

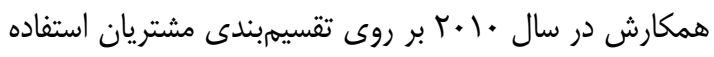

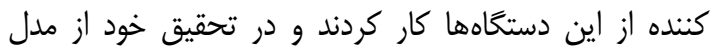

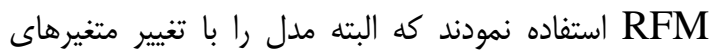
مناسب براى بانك بصورت RF*M* تعريف نموده و براى خوشهبندى آنها از الكَوريتم ULVQ استفاده كرده و مشتريان را در سا خوشه قرار دادند.

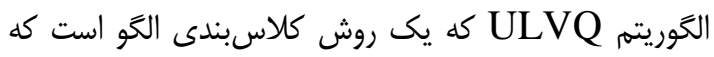

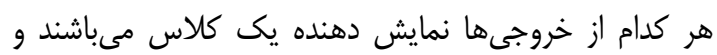

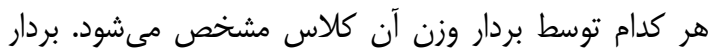

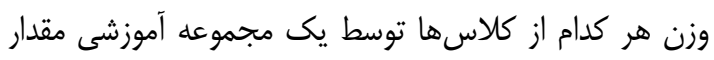
دهى اوليه شده و سيس توسط الكَوريتههاى يادگيرى (بدون

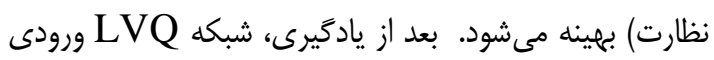
را به كلاسى كه بردارى با نزديك ترين فاصله به آن باشئد،

نسبت مىدهد. البته از معايب اين الكَوريتم مىتوان به موارد زير اشاره كرد كه باعث مىشود نتوان به تحليل درستى از خوشهها دست يافت التها قواعد يا دستورات مشخصى براى طراحى شبكه

جهت يك كاربرد اختيارى وجود ندارد.

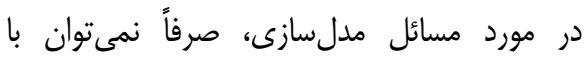

استفاده از شبكه عصبى به فيزيك مساله بى برد. به
سختى محاسبه ييشبينى ارزش بلندمدت، اعتبار و وفادارى از از

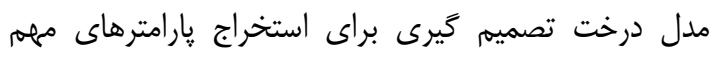
وابسته به آنها استفاده شد.

يزوهش شماره ه) بخشبندى ارزش مشترى با مدل RFM و تئورى RS

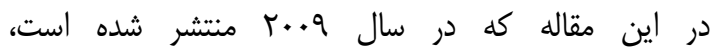
جينگ

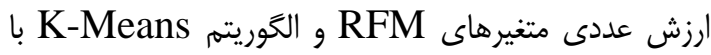
تئورى مجموعههاى سخت بيشنهاد كردند. بر اساس اين مدل

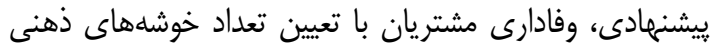

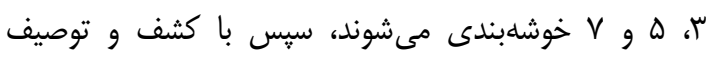
ويزگكىهاى مشتريان هر خوشه به ارزيابى و وييادهسازى مديريت ارتباط با مشترى كمك مى كنند. يزوهش شماره ع) تقسيهمبندى مشترى و توسعه استراتثى بر

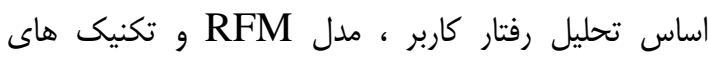

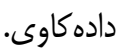

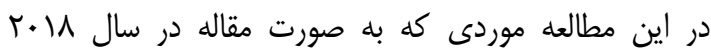
منتشر شده است، توكلى(Tavakoli) به همراه هم: همكاران دران خود در شركت ديجيكالا يك مدل بر اساس مدل RFM

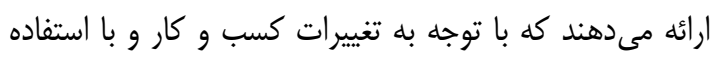
از روش خوشه بندى K-Means به تقسيهبندى مشتريان

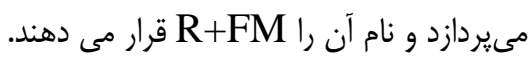

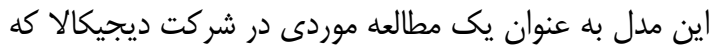

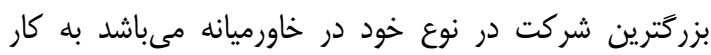

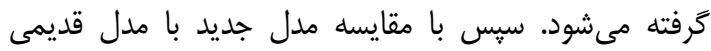

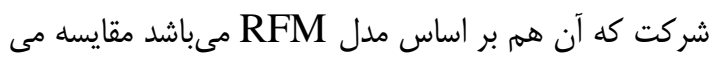

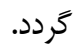
بر اساس اين مدل جديد استراتزىها بر اساس هر كدام از بخشهاى مشتريان ساخته شده و با تشكيل يك كمئ كمبين

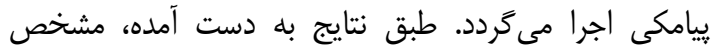

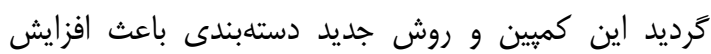
تعداد خريدها و ميانكين مبالغ سبدهاى خريد كرديديد

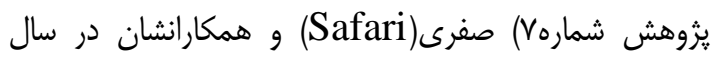

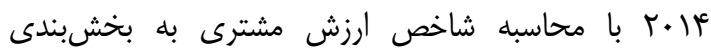

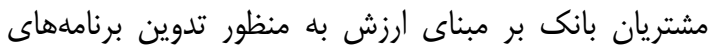

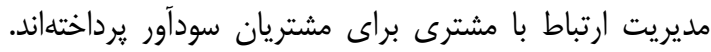

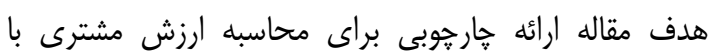

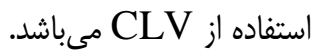

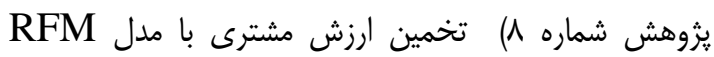




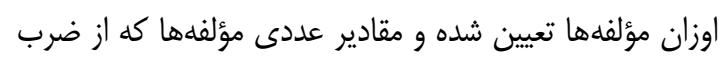

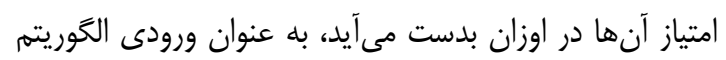

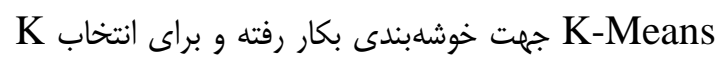

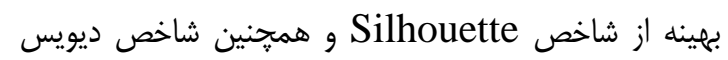

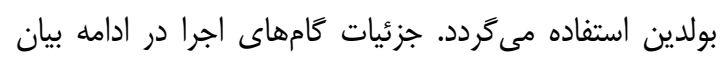

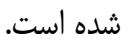
اين بخش مدل يُشنهادى براى تحليل رفتار مشتريان در

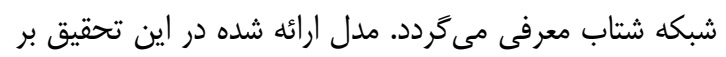

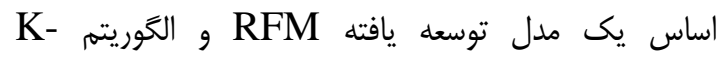
Means مىباشد. مدل Re مدل تام كذارى شده است.

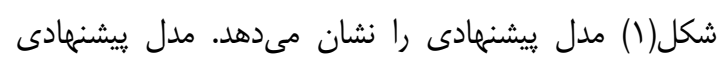

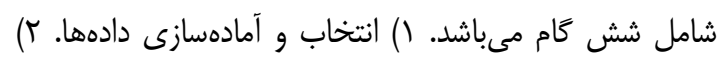

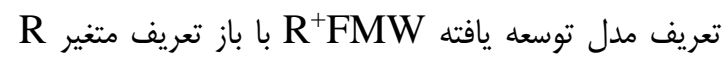

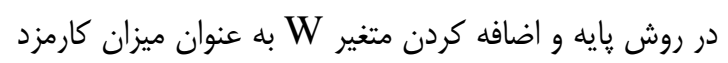

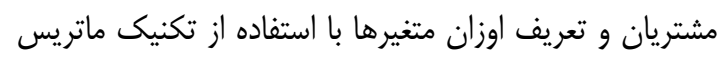

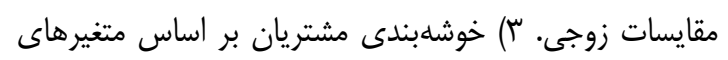

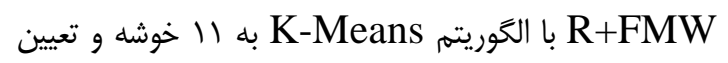
K بهينه با شاخصهاى ديويس بولدين و سيلهورت خوشهبندى مشتريان بر اساس RFM جهت مقايسه نتايج با

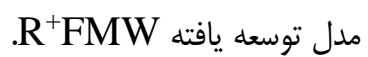
ז) محاسبه امتياز هر خوشه به صورت:

$$
C^{i}=W_{R+} C_{R+}^{i}+W_{F} C_{F}^{i}+W_{M} C_{M}^{i}+W_{W} C_{W}^{i}
$$

به طوريكه

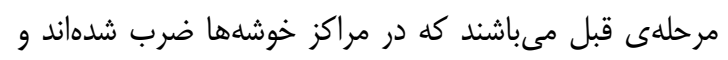

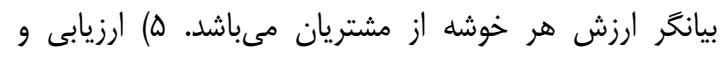

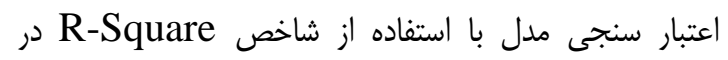
مقايسه با RFM إيها فرآيند تحقيق به صورت كام به كام و بائ بهره كايه كيرى از متدلوزى CRISP به شرح زير انجام شد:

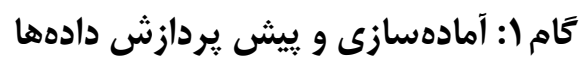

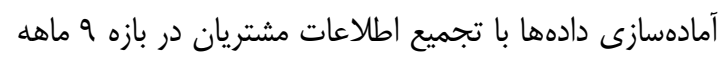

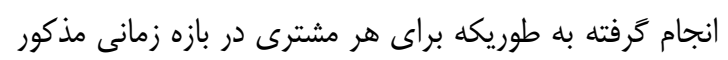

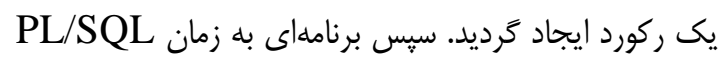

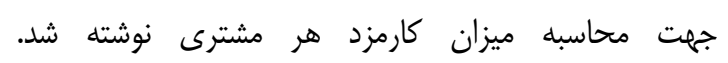
ركوردهايى كه داراى مقادير تهى هستند و مشتريانى كه فقط

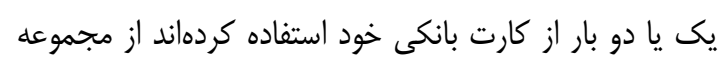

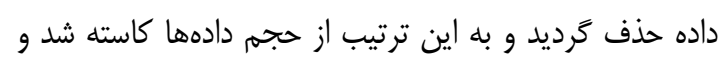
عمليات كشف دانش آسانتر كرديد

كام Yم: تعريف مدل توسعه يافته R+FMW
عبارت ديخر مرتبط ساختن يارامترها يا ساختار شبكه به

$$
\text { يارامترهاى فر آيند معمولاً غير ممكن است. }
$$

ا. . دقت نتايج بستخى زيادى به اندازه مجموعه آموزش دارد.

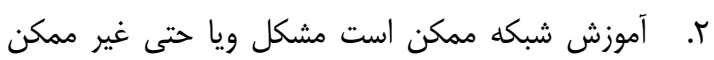

باشد.

r. ييشيينى عملكرد آينده شبكه (عموميت يافتن) آن به سادگى امكان بذير نيست.

\section{روش تحقيق}

هدف تحقيق بخشبندى مشتريان در شبكه شتاب با توسعه

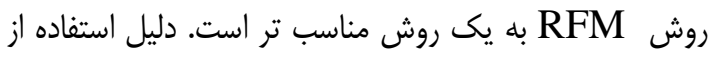

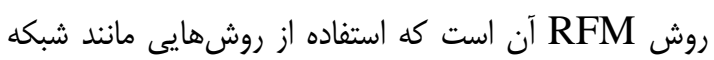

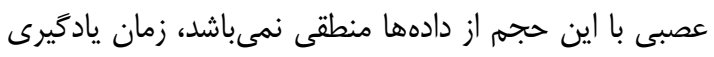

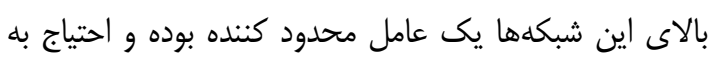

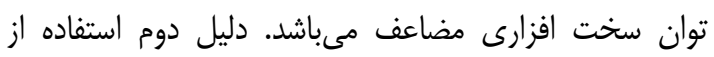

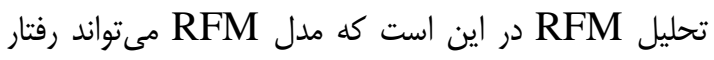

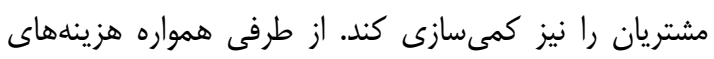

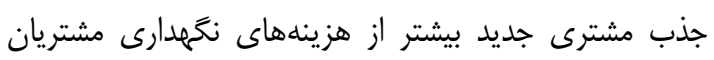

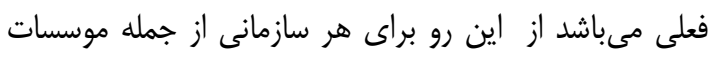

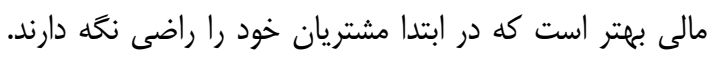

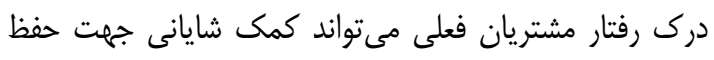

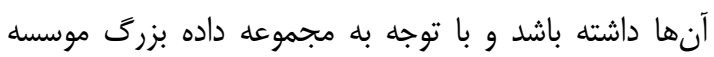

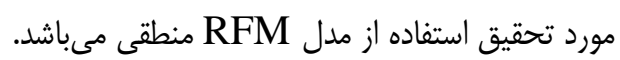

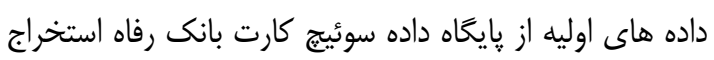

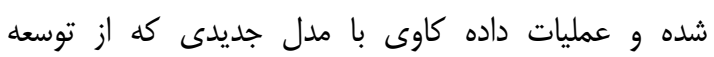

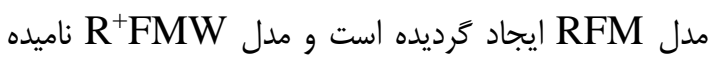

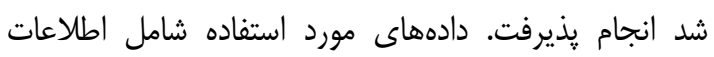

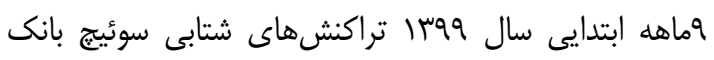

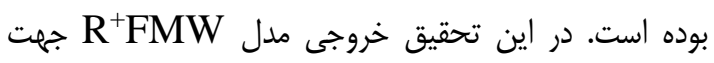

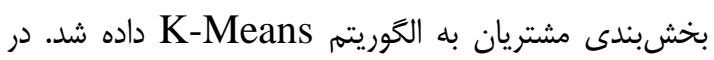
واقع مدل ارائه شده در اين تحقيق تركيب مدل توسعه يافته R+FMW و الكوريتم از الكوريته K-Means اين است كه در روش سنتى

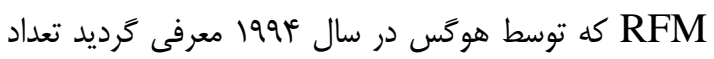

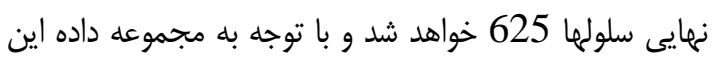

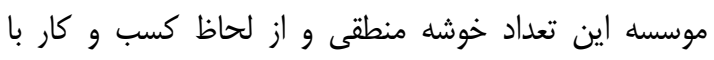

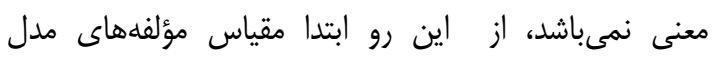

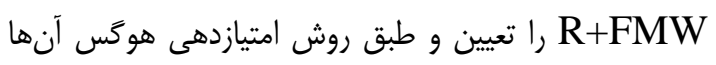

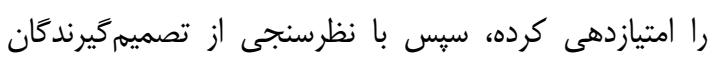

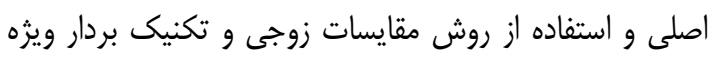


تقوى فرد ، خانيو لطفى:خوشهبندى مشتريان در حوزه بانكدارى الكترونيك با بهره گيرى از تراكنشهاى الكترونيكى و اطلاعات دمو كرافيك (مورد

مطالعه: بانكك رفاه)

هر مؤلفه به ه قسمت مساوى تقسيم شده و به ترتيب اولويت إنها

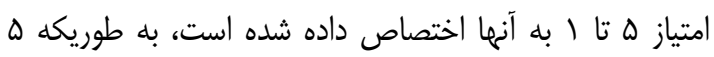

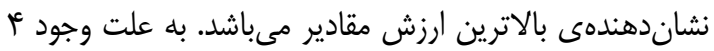

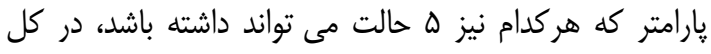

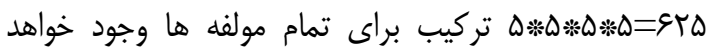

كامسّ: خوشهبندى مشتريان براساس متغيرهاى

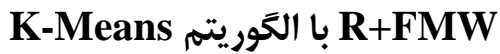
دراين مرحله بعد از تعريف متغيرهاى مدل R+FMW اين

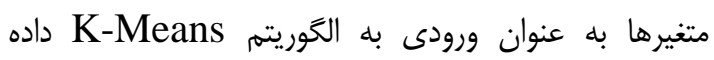
مىشود. براى تعيين تعداد خوشه بهينه از إن شاخصهاى

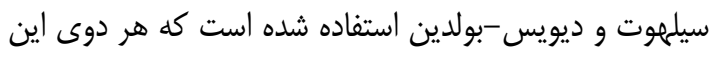

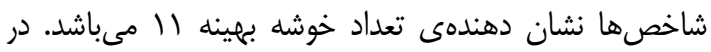

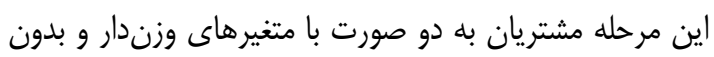

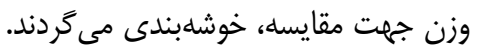

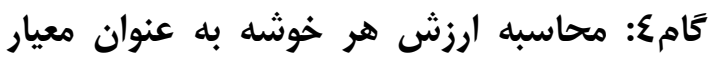

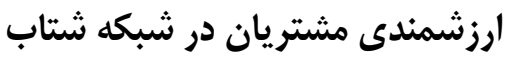

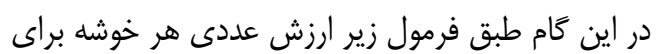
i i $1 \leq 11$

$$
C^{i}=W_{R+} C_{R+}^{i}+W_{F} C_{F}^{i}+W_{M} C_{M}^{i}+W_{W} C_{W}^{i}
$$
بطوريكه ضرايب متغيرهاى فرمول فوق، وزنهاى محاسبه

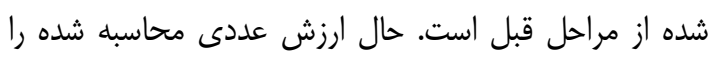

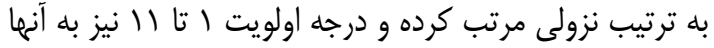
اختصاص داده مىشود، به طوريكه مشتريان با با امتياز خوشه نئه

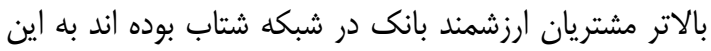

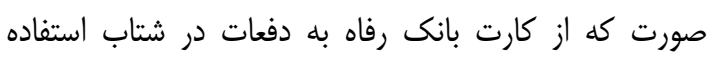
كردهاند و كمترين كارمزد را به بانك تحميل كرده اند.

\section{كام ه: ارزيابى و اعتبار سنجى مدل}

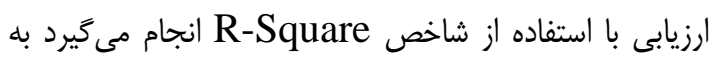

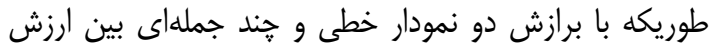

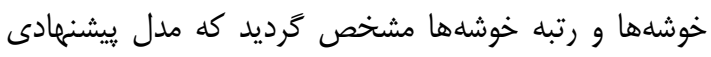
نسبت به مدل RFM يايه دقت بالاترى دارد.
مدل RFM به طور كلى براى صنعت خرده فروشى مناسب است و خاص محيط هاى بانكى نيست. در اين مطالعه با بالي

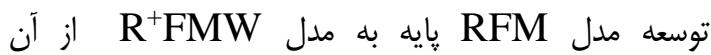
مى توان براى تحليل رفتار مشتريان بانكى در شبكه شتاب

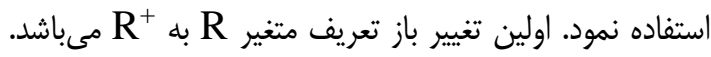

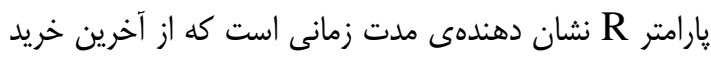

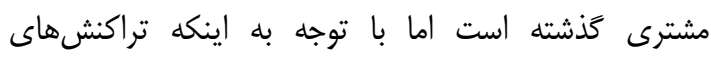

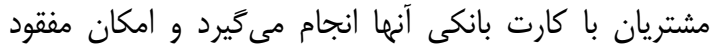

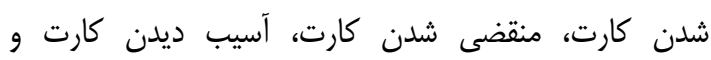

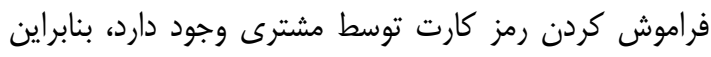

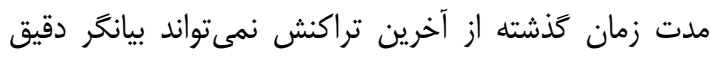

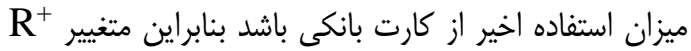

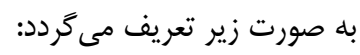
= آخرين ماهى كه كارت بانكى تراكنش داشته است

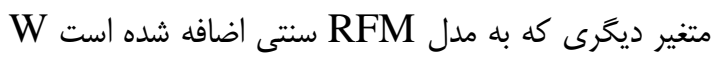

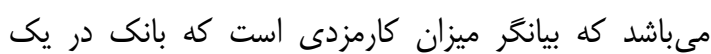

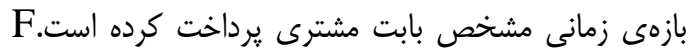
مجموع تراكنشهاى يك مشترى در بازمى زمانى مشخص برد

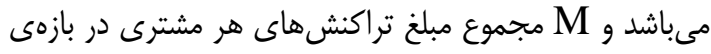

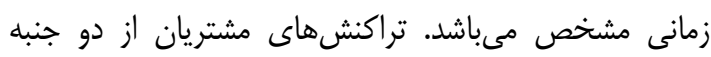
قابل بررسى مىباشد:

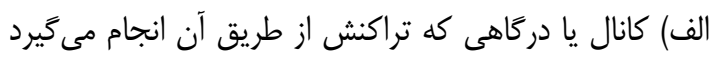
كه شامل ه كانال است:

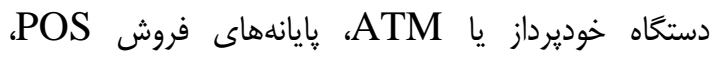

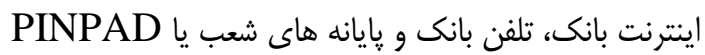
ب) نوع تراكنش مشترى كه مىتواند شامل موارد زير باشد:

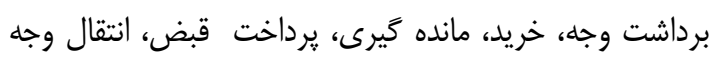

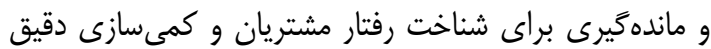

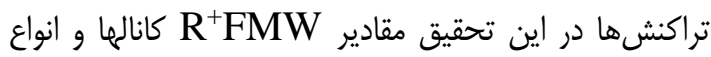
تراكنش ها محاسبه شده است.

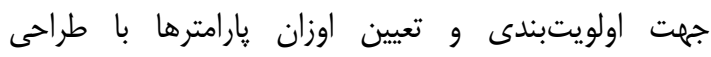
يرسشنامه به نظرسنجى از تصميمَيرندًان اصلى توسط

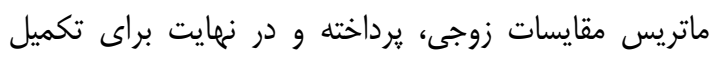

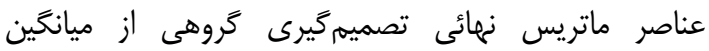

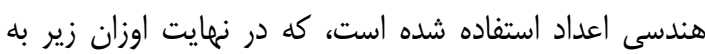
دست آمد:

$\mathrm{W}_{\mathrm{R}+}=0.13, \mathrm{~W}_{\mathrm{F}}=0.2, \mathrm{~W}_{\mathrm{M}}=0.24$

$$
\text { , } \mathrm{W}_{\mathrm{W}}=0.43
$$

براى مقياس دهى مؤلفهاى مدل مطابق امتيازدهى هوكّ،

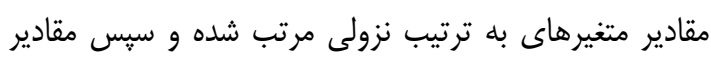




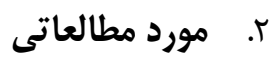

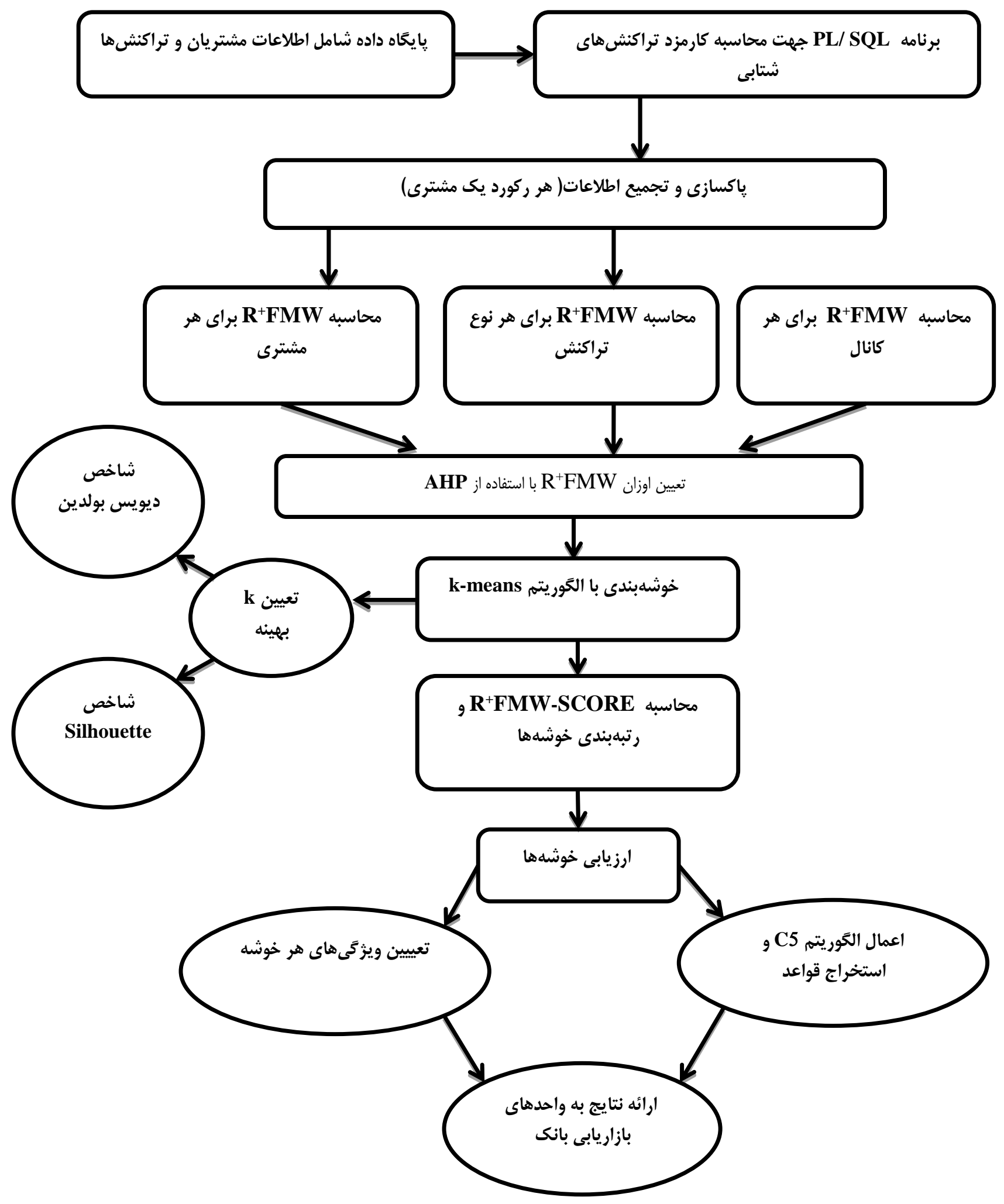


تقوى فرد ،خانيو لطفى:خوشهبدى مشتريان در حوزه بانكدارى الكترونيك با بهره گيرى از تراكنشهاى الكترونيكى و اطلاعات دمو گر افيك (مورد

مطالعه: بانكك رفاه)

بازه زمانى نه ماهل يك ركورد وجود داشته باشد. در ابتدا تعداد

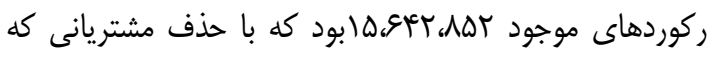

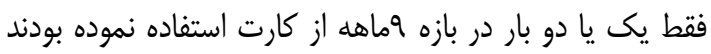

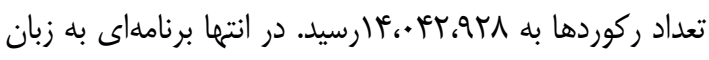

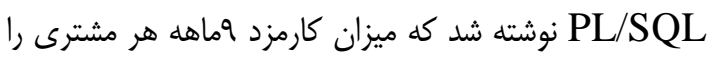
محاسبه مى كند.

Rامץ ) تعريف و مقياس دهى مدل R'FMW

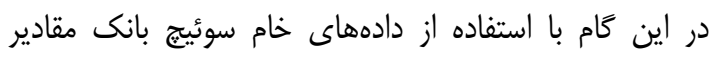

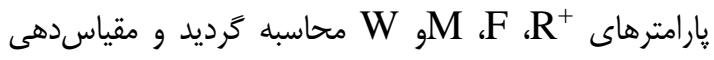
مقادير طبق روش هوگس مطابق جدول (َّ) انجام شد.

\section{جدول r.مقياس متغير هاى R+FMW}

\begin{tabular}{ccccc}
\hline Scale & $\mathrm{R}^{+}$ & $\mathrm{F}$ & $\mathrm{M}$ & $\mathrm{W}$ \\
\hline 5 & 9 & 32962 & 230592162510 & 26042 \\
\hline 4 & $7-$ & 118 & 102169500 & 76275 \\
& 8 & & & \\
\hline 3 & $5-$ & 61 & 56782050 & 167356 \\
& 6 & & & \\
\hline 2 & $3-$ & 32 & 25455000 & 349705 \\
& 4 & & & \\
\hline 1 & $1-$ & 13 & 8500000 & 43107085 \\
& 2 & & & \\
\hline
\end{tabular}

با تحليل رفتار مشتريان مقادير متغيرهاى Rماي

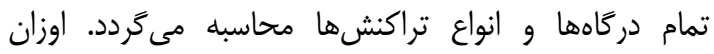

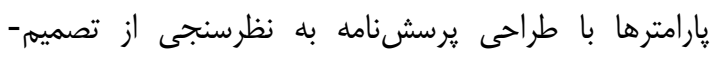

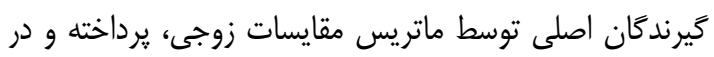

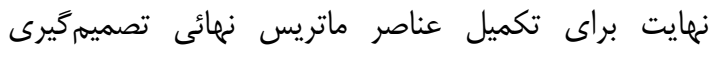

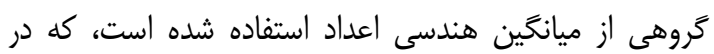
نهايت اوزان زير بدست آمد:

$\mathrm{W} \mathrm{R}+=0.13, \mathrm{WF}=0.2, \mathrm{WM}=0.24$, $\mathrm{WW}=0.43$

\section{كامس خوشهبندى با الكوريتم K-Means} در اين مرحله مشتريان بانك رفاه كاركَران توسط الكوريته

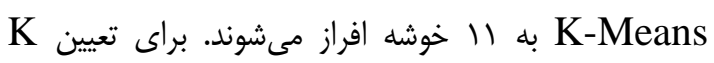

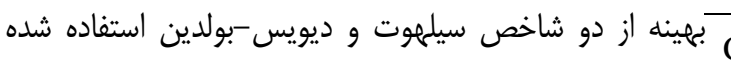
است. در شكل זو ب مقادير اين دو شاخص با تعداد خوشهها
مدل ييشنهادى در بانك رفاه كاركران يِياده سازى گَرديد. اين

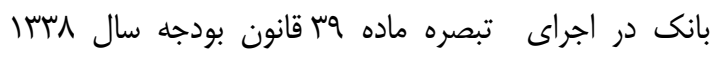

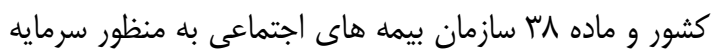

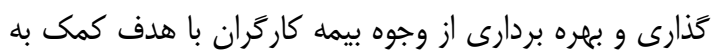

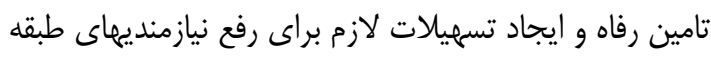

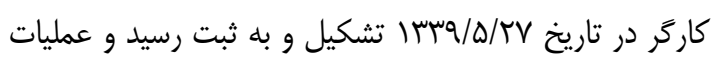

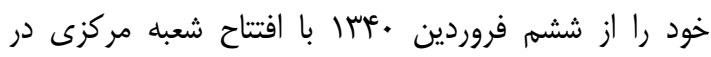
تهران و شعبه اصفهان آغاز كرد.

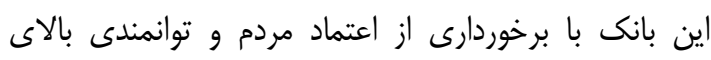

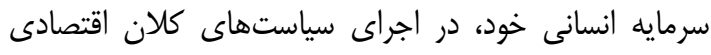

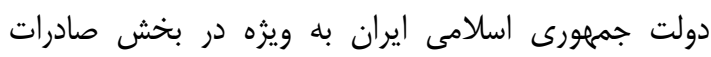
كالاهاى غير نفتى و توليدات صنعتى و كشاورزى، خدمات آندات ارزشمندى را به صادر كنندكان كشور ارائه مى فهد.

جدول (. كارمزد يرداختى بانكى رفاه در شبكه شتاب(ميليارد ريال)

\begin{tabular}{|c|c|c|c|}
\hline شرح & سال qV & سال 91 & سال 99 \\
\hline كردارتنى & & r.var & r. \\
\hline كريارمتى & Tצ"ד. & T.FAT & r.r.. \\
\hline
\end{tabular}

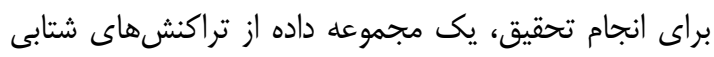

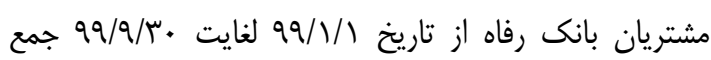

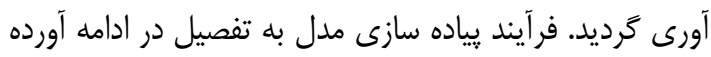

$$
\text { شده است: }
$$

\section{كام (ا آماده سازى و بيش يردازش دادهها}

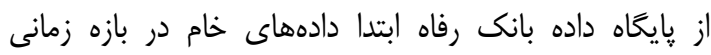

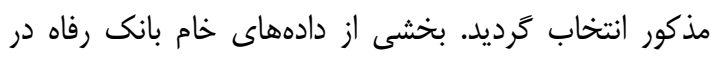
جدول (r) نمايش داده شده است.

جدول. بخشى از داده هاى سوئيج كارت بانكى رفاه كارتران

\begin{tabular}{lccc}
\hline CardId & TRANS-TYPE & TRANS- & TRANS \\
CHANNEL & AMOUN
\end{tabular}

\begin{tabular}{|c|c|c|c|}
\hline ـنشا. داده شده است & & & $\mathrm{T}$ \\
\hline 4364 & PURCHASE & POS & 450000 \\
\hline 4364 & $\begin{array}{c}\text { WITHDRAWA } \\
\text { L }\end{array}$ & ATM & 300000 \\
\hline 3514 & $\begin{array}{c}\text { BILLPAYMEN } \\
\mathrm{T}\end{array}$ & $\begin{array}{c}\text { INTERNE } \\
\mathrm{T}\end{array}$ & 48200 \\
\hline
\end{tabular}




\begin{tabular}{|c|c|c|c|}
\hline 9 & 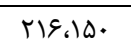 & 1.15895 & $r$ \\
\hline v & 1.001 .694 & 1.20662 & 1 \\
\hline$\wedge$ & $r .9 .019$ & 0.84111 & $\wedge$ \\
\hline 9 & r.TYG.TV & 0.83203 & 9 \\
\hline 1. & $18 V 9.194$ & 1.06109 & r \\
\hline 11 & rar.ved & 0.76575 & 11 \\
\hline
\end{tabular}

\section{r. يافته ها و نتيجه تَيرى}

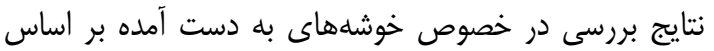

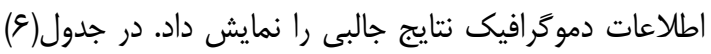
و جدول(V) جنسيت و سن مشتريان هر خوشه نشان دانيك دادي

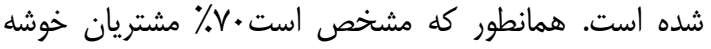
شماره V كه مشتريان طلايى بانك هستند را خانمها تشكيل مشتريان دادهاند و در بقيه خوشهها غالب مشتريان آقا هستند.

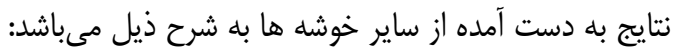

خوشه شماره ((مشتريان فعال با كارمزد بالا)

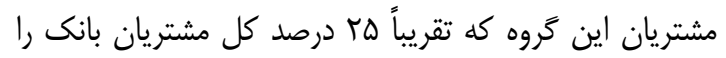
به خود اختصاص مى دهند، مشتريانى با بيشترين ميزان كارمزد

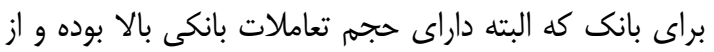

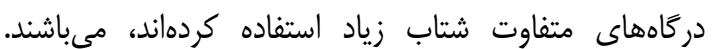
• ودرصد مشتريان آقا و • Vدرصد سن بالاى • • عال دارند. داراى كمترين ارزش خوشهاى هستند. البته با توجه به حجم باله تعاملات بانكى بالاى اين مشتريان، بانك مىتواند برنامههاى

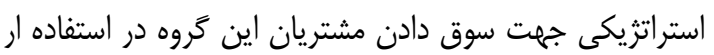
درگاههاى بانك رفاه كارگران اقدام نمايد. جدول 7.جنسيت مشتريان

\begin{tabular}{|c|c|c|c|c|}
\hline \multirow{2}{*}{\multicolumn{2}{|c|}{ 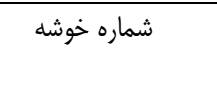 }} & \multicolumn{3}{|c|}{ جنسيت بر حسب درصد } \\
\hline & & مرد & زن & \\
\hline 1 & & 96.61 & 3.39 & \\
\hline r & & 68.67 & 32.33 & \\
\hline r & & 97.4 & 2.6 & \\
\hline f & & 97.85 & 2.15 & \\
\hline$\Delta$ & & 97.54 & 2.46 & \\
\hline 8 & & 98.85 & 1.15 & \\
\hline$\checkmark$ & & 29.88 & 70.12 & \\
\hline$\wedge$ & & 98.02 & 1.98 & \\
\hline 9 & & 97.91 & 2.09 & \\
\hline 1. & & 97.03 & 2.97 & \\
\hline 11 & & 98.39 & 1.61 & \\
\hline مجموع & & 97.51 & 2.49 & \\
\hline \multicolumn{5}{|c|}{ جدول لتركيب سنى مشتريان } \\
\hline شماره & \multicolumn{4}{|c|}{ تروه سنى برحسب درصد } \\
\hline 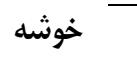 & $<25$ & $25-35 \quad 36-46$ & $47-60$ & $>60$ \\
\hline 1 & 2.41 & 19.64 & 31.82 & 26.92 \\
\hline
\end{tabular}

شكل Y. K بهينه با شاخص سيلمهووت

شاخص Silhouette

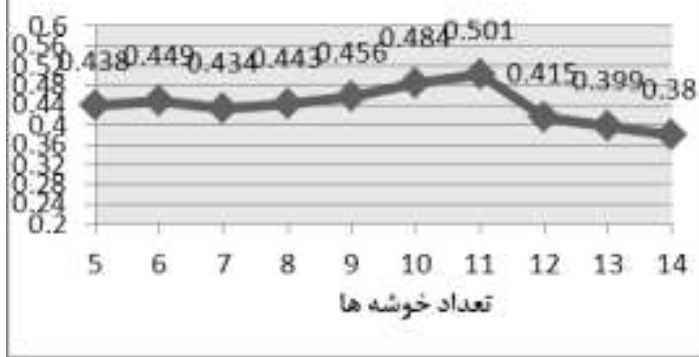

شكل س. K بهينه با شاخص ديويس بولدين

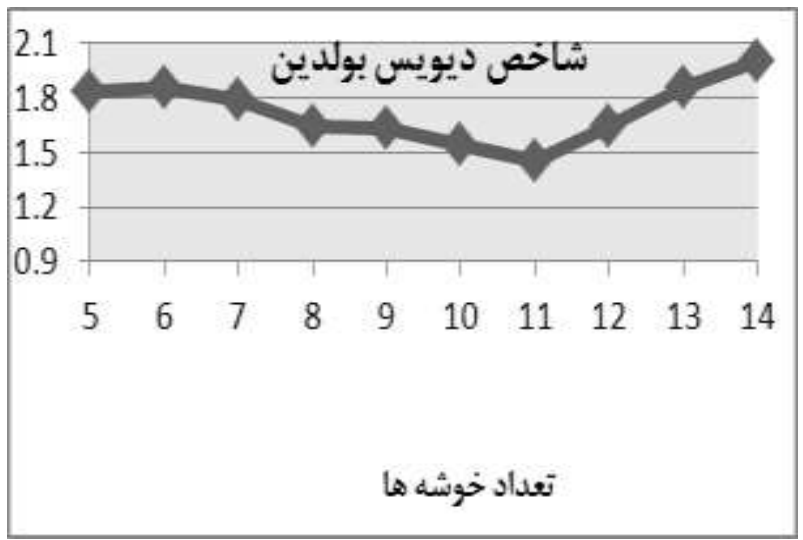

نتايج خوشهبندى با || خوشه در جدول (أ) نشان داده شده

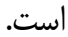
جدول ع. مقايسه دقت روش بيشنههادى

\begin{tabular}{|c|c|c|}
\hline & R2 /F خطى R2 & R2/F جندجمله اى \\
\hline مدل ييشنهادى &.$/ 98$ &.$/ 914$ \\
\hline مدل RFM سنتى &.$/ 4 \wedge \mu$ & | \\
\hline
\end{tabular}

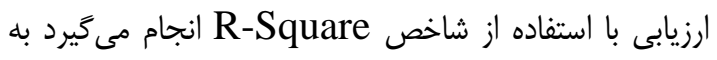

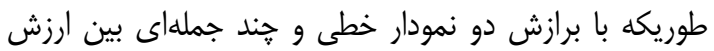

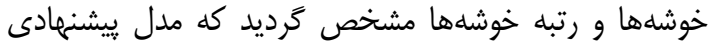

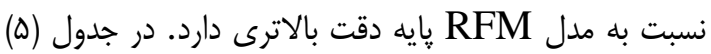
نتايج نشان داده شده است

جدول ه. نتايج خوشهبندى K-Means

\begin{tabular}{|c|c|c|c|}
\hline شماره & تعداد & محاسبه ارزش & رتبه \\
\hline خوشه & مشتريان & خوشه & خوشه \\
\hline 1 & $r .4+0.891$ & 0.76618 & 1. \\
\hline r & $1, \cdots+.9 \Delta \wedge$ & 1.01497 & $\Delta$ \\
\hline$\mu$ & 1. & 1.04029 & f \\
\hline f & $r \cdot a|r|$ & 0.86062 & $\checkmark$ \\
\hline$\Delta$ & r.19Y.Gr) & 0.90028 & 9 \\
\hline
\end{tabular}


تقوى فرد ، خانيو لطفى:خوشهبندى مشتريان در حوزه بانكدارى الكترونيك با بهره گيرى از تراكنشهاى الكترونيكى و اطلاعات دمو كرافيك (مورد

مطالعه: بانكك رفاه)

اين كروه حجم تعاهلات پإيينى دارند كه به نسبت آن هم

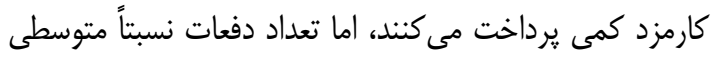
دارند و هميشه از كارت بانك خود استفاده مئك كنند. بيشترين

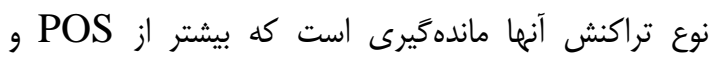

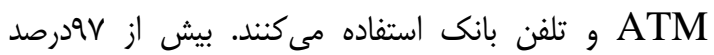

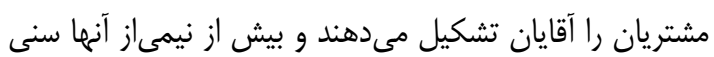
بين •r تا مأ سال دارند.

\section{خوشه شماره 7 (مشتريان خوب)}

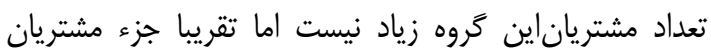

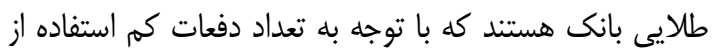
دركاههاى شتاب داراى حجم تعاملات مالى بالا و البته داراى

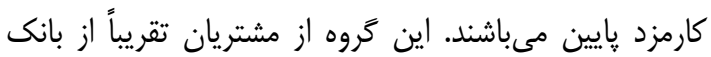

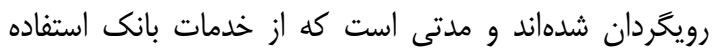

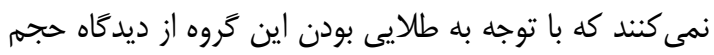

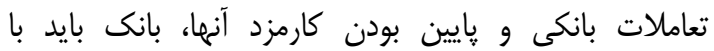

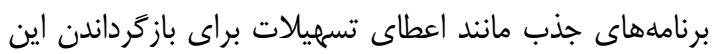

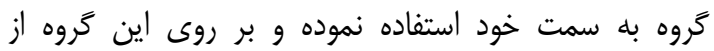

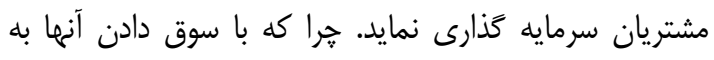
سمت بانك به سودآورى بيشتر و جذب مشتريان بمان بيشتر دست

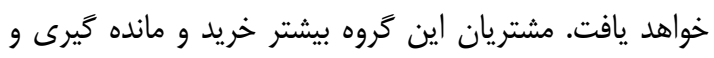

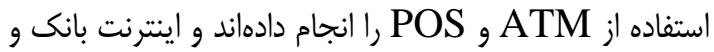

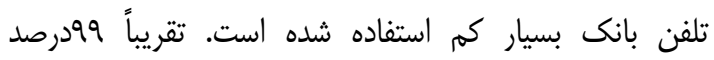
مشتريان اين گروه آقا هستند كه بيش از •م درصد آنهان آنها كمتر

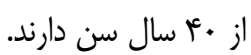

\section{خوشه شماره V (مشتريان طلايى) ارنل} رتبه يك به اين گروه از مشتريان اختصاص يافتهانه است كهان

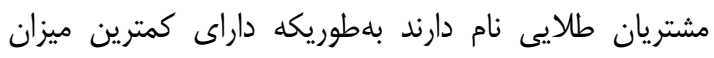

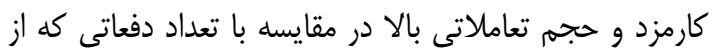

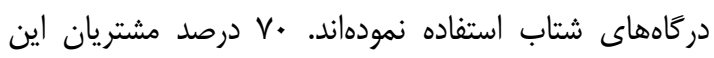

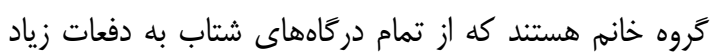

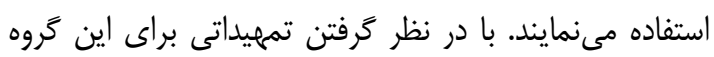

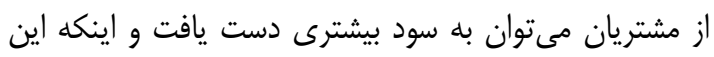

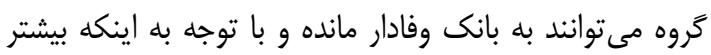

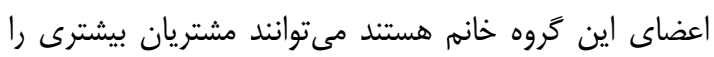
به بانك معرفى نمايند. دادن تسهيلات مناسب به إهائ اين دسته

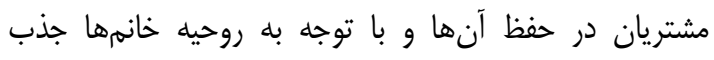
مشتريان مشابه خود را به همراه خواهد داشت.

خوشه شماره ^ (مشتريان فعال در مران يرداخت قبوض)

\begin{tabular}{|c|c|c|c|c|c|}
\hline$r$ & 18.57 & 38.51 & 23.40 & 16.78 & 2.75 \\
\hline$r$ & 3.09 & 23.92 & 21.32 & 26.61 & 25.06 \\
\hline F & 7.02 & 32.03 & 20.34 & 21.32 & 19.29 \\
\hline$\Delta$ & 6.57 & 27.15 & 21.10 & 21.32 & 23.85 \\
\hline 8 & 5.02 & 35.21 & 26.28 & 20.89 & 12.60 \\
\hline$v$ & 4.63 & 25.01 & 20.67 & 23.85 & 25.84 \\
\hline$\Lambda$ & 5.68 & 34.61 & 24.82 & 22.29 & 12.60 \\
\hline 9 & 8.91 & 32.37 & 21.78 & 19.19 & 17.75 \\
\hline 1. & 5.58 & 24.19 & 19.67 & 24.23 & 26.33 \\
\hline 11 & 8.06 & 36.16 & 22.03 & 17.38 & 16.38 \\
\hline مجموع & 5.55 & 26.72 & 21.01 & 24.05 & 22.68 \\
\hline
\end{tabular}

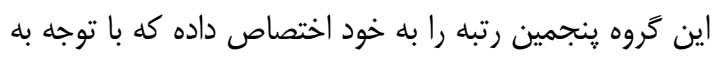

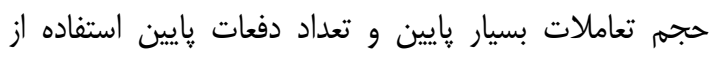

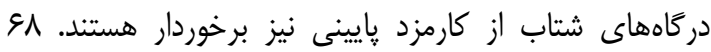

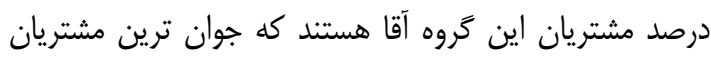

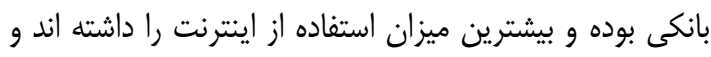

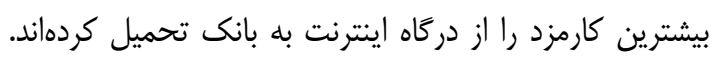

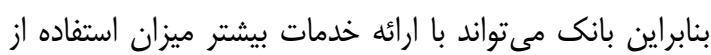
اينترنتبانك را بين طيف وسيعترى از مشتريان داشته باشد.

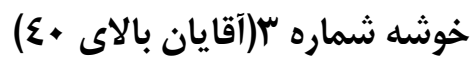

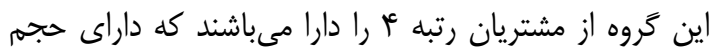

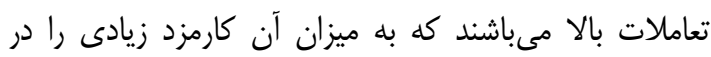

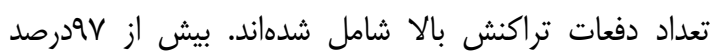

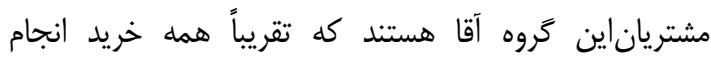

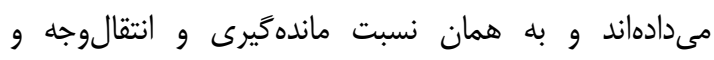

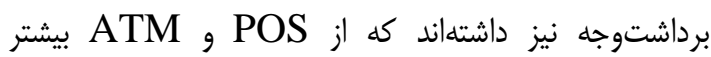

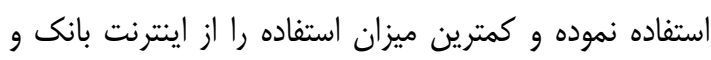

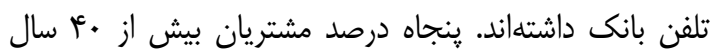

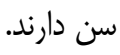

\section{خوشه شماره §(آقايان علاقهمند به تلفنبانك)}

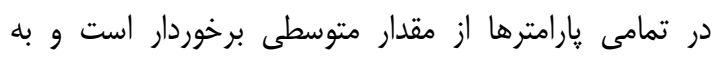

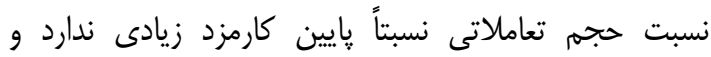

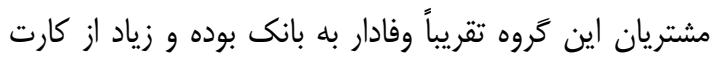

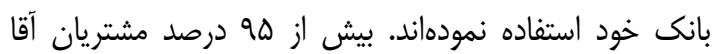

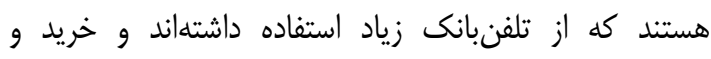

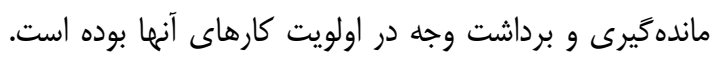

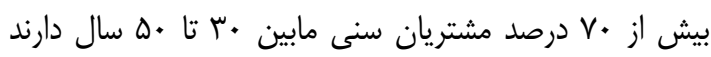
كه قشر ميانسال را تشكيل مى دهند مشند. خوشه شماره 0(مشتريان مانده مير!) 
كنندهمجنين مدل جامعى كه جهت خوشه بندى مشتر مشتريان بانك ارائه كرديد، مىتواند مشتريان فعال در شبكه تبادل بين

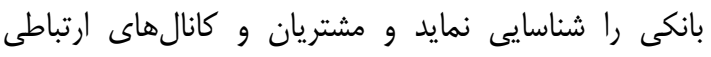
يرهزينه را از جنبهى ميزان كارمزد تشخيص دهند.

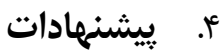

در اين يزوهش تعيين رتبهبندى مشتريان براساس بارامترهاى

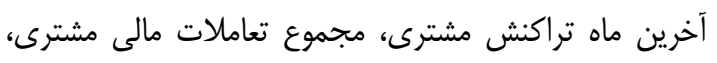

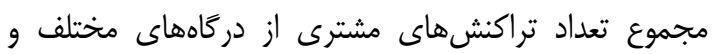
مجموع كارمزد برداختى مشترى توسط موسسه مالى محاسبه

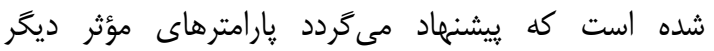
شناسائى و به اين مدل افزوده كردد.

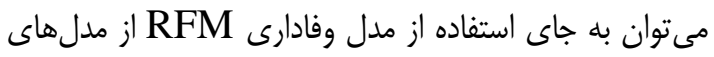

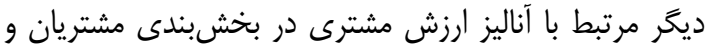
همجنين غير از الكوريته ديخر خوشهبندى استفاده شود. در ضمن جهت تحقيق بيشتر در اين حوزه ييشنهاد مى مرددد،

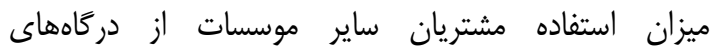
الكترونيكى موسسه حاضر نيز مورد بررسى قرار كيرد و ميزان علاقمندى ساير مشتريان به دركاههاى الكترونيكى موسسه مورديه نيز مورد بررسى قرار كيرد.
اين مشتريان داراى كارمزد بالايى هستند كه در استفاده از

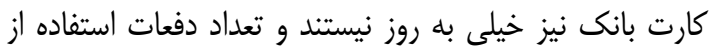

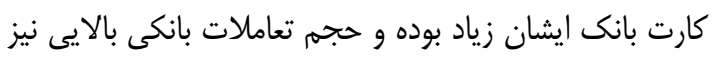
دارند. بيشتر از دستكاه POS استفاده نموده و عمدتاً كارهاى باري

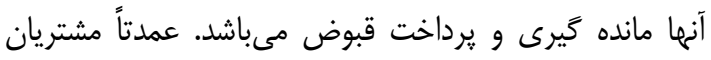

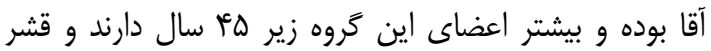
جوانى هستند.

\section{خوشه شماره 9 (آقايان غير فعال)}

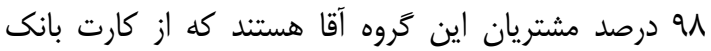

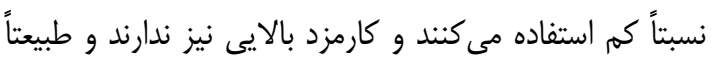

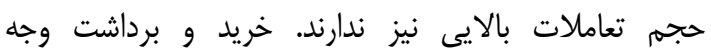

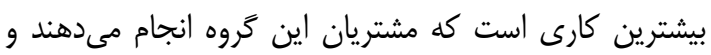
عمدتاً از ATM استفاده مي كنند.

\section{خوشه شماره + 1 (مشتريان جوان)}

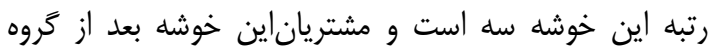

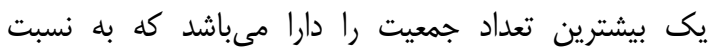

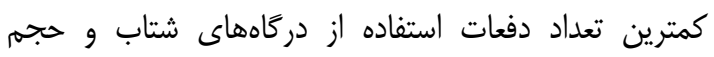

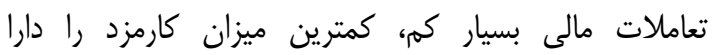

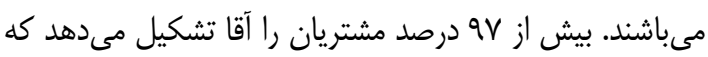
بيشتر خريد و مانده كَيرى و برداشت وجه انجام مى ديدادهاند و از ATM و POS

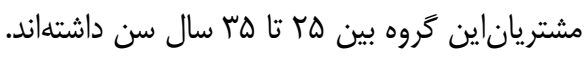
خوشه شماره | (ال (مشتريان هزينهزا)

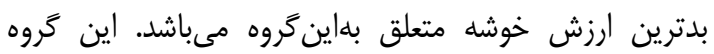
بيشترين كارمزد را دارا مىباشند در حاليكه حجم تعاملاتلات آنها

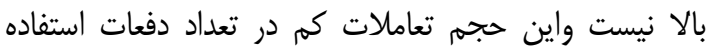

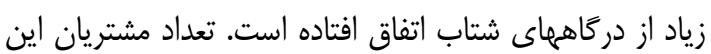

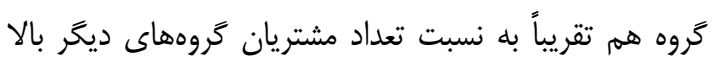

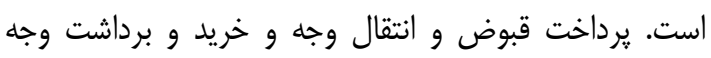

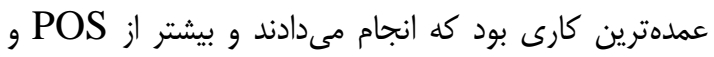

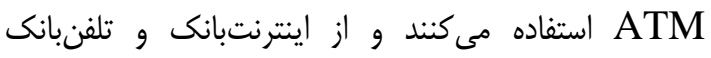

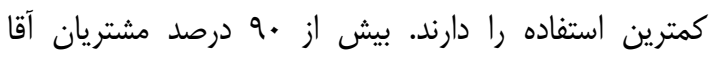

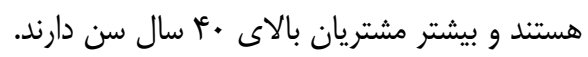

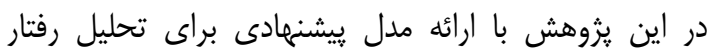

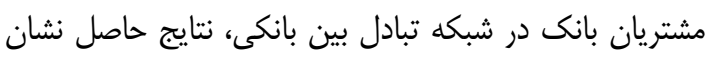

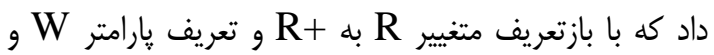
تعيين اوزان با روش ماتريس مقايسات زوجى به نتايج بهترى جهت تحليل ميزان سودمندى مشتريان در شبكه تبادل بين باني

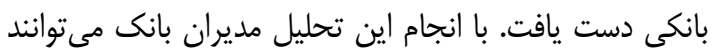
مشتريان فعال كه كمترين ميزان كارمزد را داشته اند شناسايى باني 


$$
\text { تقوى فرد ،خانيو لطفى:خوشهبندى مشتريان در حوزه بانكدارى الكترونيك با بهره گيرى از تراكنشهاى الكترونيكى و اطلاعات دمو گرافيك (مورد }
$$

Stone, B., Successful Direct Marketing Methods, Seventh Edition 7thed, McGraw-Hill, 2001, pp. 37-57

Tavakoli, Molavi, Masoumi, Mobini, Etemad, Rahmani, Customer Segmentation and Strategy Development based on User Behavior Analysis, RFM model and Data Mining Techniques: A Case Study, 15th International Conference on eBusiness Engineering (ICEBE),2018, pp.119-126.

Tsiptsis, Chorianopoulos, Data Mining Techniques in CRM: Inside Customer Segmentation, 2009, John Wiley \& Sons, Ltd.

Natalia, Fortuna, Leonita, Segmentation of Mobile Applications Users:Classification of Customer ELoyalty Behavior in Online Shopping Platform, International Conference on Information Management and Technology(ICIMTech), 2020,pp.126129.

Wu, J., \& Lin, Z. (2005). Research on customer segmentation model by clustering. ACM International Conference Proceeding Series, 113

Zhou, Review of Customer Segmentation method in CRM, 2011, ieee.

Bizhani Mehdi, Tarokh Mohammad Jafar, Behavioral Segmentation of Bank's Point-of Sales using RF*M* Approach, IEEE, 2010.
Cheng," Classifying the segmentation of customer value via RFM model and RS theory",2009, Expert Systems with Applications 36 (2009) 4176-4184

Ching-Hsue, You-Shyang, Classifying the segmentation of customer value via RFM model and RS theory, Expert Systems with Applications, 2009, pp.4176-4184.

Dursun and Caber, Using data mining techniques for profiling profitable hotel customers: An application of $\mathrm{rfm}$ analysis. Tourism management perspectives, 2016,pp.153-160.

Han, J., \& Kamber, M. (2001). Data mining: Concepts and techniques. San Francisco: Morgan Kaufmann Publishers.

Huang , Zhang, Yue He, Research on improved RFM customer segmentation model based on K-Means algorithm, 5th International Conference on Computational Intelligence and Applications (ICCIA), 2020, pp. 2427.

Hughes, “A. M. Strategic database marketing. Chicago: Probus Publishing Company", 1994.

Khajvand, Zolfaghar, Ashoori, Alizadeh, Estimating customer lifetime value based on RFM analysis of customer purchase behavior: case study, Procedia Computer Science, 2011, pp.57-63

Romdhane,An efficient approach for building customer profiles from business data,2010, Expert Systems with Applications 37 (2010) 15731585

Safari Kahreh, Tive, Babania, Hesan, Analyzing the applications of customer lifetime value (CLV) based on benefit segmentation for the banking sector, Procedia-Social and Behavioral Sciences, 2014, pp.590594. 